\title{
Neurotensin Promotes Oscillatory Bursting Behavior and Is Internalized in Basal Forebrain Cholinergic Neurons
}

\author{
Angel Alonso, Marie-Pierre Faure, and Alain Beaudet \\ Montreal Neurological Institute and McGill University, Montreal, Quebec, Canada H3A-2B4
}

Cholinergic neurons of the basal forebrain magnocellular complex (BF) constitute the primary source of ACh to the cerebral cortex and are thought to be instrumental in mediating cortical activation and plasticity. Recent light and electron microscopic studies have revealed a selective association of receptors for the neuropeptide neurotensin (NT) with BF cholinergic neurons, suggesting that this peptide may be playing a key role in the control of BF cholinergic function. In the present study, we have investigated by means of intracellular recording in guinea pig brain slices the neuromodulatory actions of NT on the intrinsic excitability of BF cholinergic neurons that were identified electrophysiologically by their low-threshold discharge, slow afterhyperpolarization, and transient outward rectification (TOR). In all cholinergic neurons tested $(n=39)$, bath application of NT (20-200 nM for 1-4 min) produced, via a direct mechanism, a membrane potential depolarization associated with a decrease in apparent input conductance. Most significantly, NT led to the emergence of a very prominent slow rhythmic bursting pattern that could shape into complex spindle-like sequences that were intrinsically generated by the cholinergic cells. These NT actions were also accompanied by a reduction of both the slow afterhyperpolarization and TOR. Bursting oscillations relied on the activation of $\mathrm{Ca}^{2+}$ conductances as opposed to $\mathrm{Na}^{+}$conductances, since they were absent during $\mathrm{Ca}^{2+}$-conductance block with $\mathrm{Mn}^{2+}$, but still occurred in the presence of the $\mathrm{Na}^{+}$-channel blocker TTX. NT actions were specific, since they could be reproduced by application of the active (NT 8-13) but not of the inactive (NT 1-8) fragment of the peptide. Identification of the BF cholinergic neurons as direct NT targets was further provided by confocal laser scanning microscopic demonstration of internalization of a fluoresceinylated derivative of NT (fluoNT) within biocytin-filled, electrophysiologically identified cholinergic neurons.

The results demonstrate the electrophysiological functionality of NT receptors on BF cholinergic neurons and the existence of a receptor-mediated internalization of NT in these cells. They also suggest that the peptide is an im-

Received Oct. 18, 1993; revised Feb. 17, 1994; accepted Mar. 2, 1994

We thank Dr. B. E. Jones for insightful discussions and comments on the manuscript and Caroline Chaput for photographic work. This work was supported by the Canadian Medical Research Council.

Correspondence should be addressed to A. Alonso, Montreal Neurological Institute, 3801 University Street, Montreal, PQ, Canada, H3A-2B4.

Copyright (C) 1994 Society for Neuroscience $0270-6474 / 94 / 145778-15 \$ 05.00 / 0$ portant player in the control of BF function and, in particular, in the generation of forebrain network oscillations.

IKey words: neurotensin, $\mathrm{ACh}$, basal forebrain, internalization, oscillations, intracellular recording]

The basal forebrain magnocellular complex (BF) constitutes the major source of cholinergic innervation to the cerebral cortex (Shute and Lewis, 1967; Rye et al., 1984), and compounded evidence indicates that $\mathrm{BF}$ cholinergic neurons play a critical role in the control of cortical arousal. Thus, $\mathrm{ACh}$ has long been known to be maximal during cortical activation (Kanai and Szerb, 1965; Celesia and Jasper, 1966; Jasper and Tessier, 1971) and to decrease with the disappearance of low-voltage fast activity (the typical EEG desynchronized or arousal pattern) following lesions of the BF (Lo Conte et al., 1982; Stewart et al., 1984; Buzsàki et al., 1988). In turn, stimulation of the $\mathrm{BF}$ has been shown to result in cortical $\mathrm{ACh}$ release and cortical activation (Belardetti et al., 1977; Casamenti et al., 1986; Kurosawa et al., 1989; Metherate et al., 1992). On the other hand, since there is also considerable evidence that the BF participates in the regulation of sleep (Sterman and Clemente, 1962; Détári and Vanderwolf, 1987; Szymusiak and McGinty, 1989), it appears that $\mathrm{BF}$ neurons may influence cortical-functional state across the sleep-waking cycle.

Over the last decade, numerous chemomorphological studies have demonstrated that the BF is in fact comprised of a heterogeneous population of neurons. The cholinergic cells appear to be outnumbered by GABAergic neurons (Onteniente et al., 1986; Gritti et al., 1993), many of which also project to the cortical mantle (Köhler et al., 1984; Zaborszky et al., 1986; Fisher et al., 1988). Moreover, a large proportion of BF neurons are peptide immunoreactive (Melander et al., 1985; Walker et al., 1989) and a profuse peptidergic innervation has been demonstrated immunohistochemically in the immediate entourage of BF cholinergic cells (Khachaturian et al., 1984; Candy et al., 1985; Haber and Watson, 1985; Smith et al., 1985; Mai et al., 1987). In this respect, the tridecapeptide neurotensin (NT) appears to occupy a strategic position in terms of putative interaction with BF cholinergic cells (Morin et al., 1993). Furthermore, both light and electron microscopic studies have demonstrated a selective association of high-affinity NT binding sites with BF cholinergic neurons (Szigethy et al., 1989, 1990).

In freely behaving rats, intracerebroventricular administration of NT has been shown to produce an awakening effect and an increase in limbic theta rhythm activity (Castel et al., 1989) that is known to accompany neocortical desynchronization (Green and Arduini, 1954; Vanderwolf, 1969, 1975, 1988). Since the cholinergic neurons of the BF play a crucial role both in 
limbic theta rhythm generation and neocortical desynchronization (Robinson et al., 1977; Bland, 1986; Buzsàki et al., 1988; Stewart and Fox, 1990), the above effects may have resulted from the actions of NT on the BF cholinergic cells.

In this context, the present study was undertaken to examine the possible neuromodulatory actions of NT on BF cholinergic neurons in guinea pig brain slices. The identification of recorded cells as cholinergic could be achieved on electrophysiological basis since a distinct property of these neurons is their voltagedependent switching from repetitive single spiking to lowthreshold doublet bursting as recently demonstrated in an electrophysiological analysis of immunohistochemically identified BF cholinergic cells (Khateb et al., 1992). Furthermore, we took advantage of a recently developed fluoresceinylated derivative of NT (fluo-NT) (Faure et al., 1992) to visualize directly the site of action of the neuropeptide, using confocal scanning laser microscopy. The present results demonstrate that NT not only binds to, but is internalized in cholinergic cells and that it directly affects multiple electrophysiological fcatures of thesc ncurons. Remarkably, NT promotes rhythmic multiple-spike burst oscillations that may develop into complex spindle-like sequences.

Preliminary results have been published in abstract form (Alonso et al., 1992).

\section{Materials and Methods}

Brain slices were derived from male guinea pigs (125-200 gm) following standard procedures. Briefly, animals were decapitated under Nembutal $(30 \mathrm{mg} / \mathrm{kg}$ ) anesthesia and the brain was rapidly removed and blocked. A slab of tissue containing the basal forebrain was placed in a cold (6$10^{\circ} \mathrm{C}$ ) oxygenated Ringer's solution (see below) and cut in the coronal plane $(400 \mu \mathrm{m})$ using a vibratome. Slices were then allowed to recover at room temperature for at least $2 \mathrm{hr}$ in oxygenated incubation chambers. For recording, a single slice was transferred to a recording chamber, submerged at $34 \pm 1^{\circ} \mathrm{C}$ and superfused with a solution containing (in mм) $124 \mathrm{NaCl}, 5 \mathrm{KCl}, 1.2 \mathrm{KH}_{2} \mathrm{PO}_{4}, 2.4 \mathrm{CaCl}_{2}, 2.6 \mathrm{MgSO}_{4}, 26 \mathrm{NaHCO}_{3}$, and 10 glucose. The pH was adjusted to 7.4 by saturating with $95 \% \mathrm{O}_{2}$ and $5 \% \mathrm{CO}_{2}$. In those experiments where $\mathrm{Mn}^{2+}$ was used to block $\mathrm{Ca}^{2+}$ conductances, a phosphate-free medium was employed. Intracellular glass electrodes were filled with $2-3 \mathrm{M}$ potassium acetate (tip resistance $60-120 \mathrm{M} \Omega$ ) or $1-2 \%$ biocytin in $2-3 \mathrm{M}$ potassium acetate $(80-150 \mathrm{M} \Omega$ ). Signals were amplified (Axoclamp 2A used in bridge mode), digitized (Neuro-Corder), visualized on line on a digital storage oscilloscope (Tektronix) as well as stored on videotape for subsequent analysis on a 386based computer. The apparent input resistance of the cells was measured from the voltage deflection induced by a $0.1-0.2 \mathrm{nA}$ hyperpolarizing current pulse from rest. Tetrodotoxin, neurotensin (NT), neuromedin$\mathrm{N}$, and the active and inactive fragments of NT (NT 8-13 and NT 18 , respectively) were purchased from Sigma. The fluoresceinylated derivative of NT (fluo-NT) was synthesized in our laboratory (M. P. Faure, P. Gaudreau, I. Shaw, N. R. Cashman, and A. Beaudet, unpublished observations). All drugs were applied to the preparation dissolved in Ringer's solution.

Slices in which neurons had been filled with biocytin were fixed with $4 \%$ paraformaldehyde in $0.1 \mathrm{M} \mathrm{PO}_{4}$ buffer for $30 \mathrm{~min}$ at room temperature, cryoprotected overnight in $0.1 \mathrm{M} \mathrm{PO}_{4}$ buffer containing $30 \%$ sucrose and sectioned at $45 \mu \mathrm{m}$ on a freezing microtome. Sections were collected in $0.1 \mathrm{M} \mathrm{PO}_{4}$ buffer, briefly rinsed in $0.1 \mathrm{M}$ Tris-saline (TBS), incubated $2 \mathrm{hr}$ at room temperature with a 1:100 dilution of streptavidin-Texas red (Jackson) in $0.1 \mathrm{M}$ TBS containing $0.1 \%$ Triton-X, washed in TBS $(3 \times 5 \mathrm{~min})$, mounted on gelatinized glass slides, and coverslipped with Aquamount. Sections were examined under a Leica confocal laser scanning microscope (CLSM) configured with a Diaplan inverted microscope equipped with an argon ion laser $[488 \mathrm{~nm}$; for the excitation of both fluorescein isothiocyanate (FITC) and Texas red] with an output power of 2-50 mV and a VME bus MC $68020 / 68881 \mathrm{com}$ puter system coupled to an optical disk for imagc storagc. Micrographs were taken from the image monitor using a Focus Image Corder (Focus, CA).
Single (10 $\mu \mathrm{m}$ thick) or serial $(0.12 \mu \mathrm{m}$ thick) optical sections were generated per scanning sequence. Images were collected at a slow scan rate $(4 \mathrm{sec} / \mathrm{scan})$ with enhanced sensitivity, and were averaged over 32 scans to improve image quality. The gain and black levels were set manually to optimize the dynamic range of the image while ensuring that no region was completely suppressed (intensity $=0$ ) or completely saturated (intensity $=255$ ). Single images were used for high-resolution recording of intracellular fluo-NT distribution and reconstructed images (i.e., stack up of 25 serial sections) were used for demonstration of double labeling.

\section{Results}

\section{Electrophysiological profile of BF cholinergic cells}

Intracellular recordings were obtained from a total of 85 neurons from a restricted region of the $\mathrm{BF}$ comprising the substantia innominata-magnocellular preoptic area and horizontal limb of the nucleus of the diagonal band of Broca (Fig. 1). A group of 54 cells in this region (to simplify hereafter refer to as BF) displayed a distinct electroresponsiveness (Figs. 2, 3) that closely corresponded to that recently demonstrated by Khateb et al. (1992) to be typical of ChAT-immunoreactive nucleus basalis neurons.

Basal forebrain cholinergic cells were characteristically silent at the resting membrane potential of $-68.3 \pm 3.3 \mathrm{mV}$ (mean $\pm \mathrm{SD}$; range, -63 to $-72 \mathrm{mV}$ ) and had an input resistance of $-62.5 \pm 17.8 \mathrm{M} \Omega$. Depolarizing current pulse injection from the resting membrane potential $\left(V_{m}\right)$ triggered in these cells an all-or-none active response that consisted of a low-threshold regenerative potential typically crowned by two (1-3) relatively broad (1-2 mscc) action potentials (Fig. $2 A$ ). Previously shown to rely on a $\mathrm{Ca}^{2+}$-dependent low-threshold spike (LTS) (Khateb et al., 1992), this response (hereafter referred to as low-threshold burst) was always both preceded by a slow ramp depolarization and followed by a large-amplitude (10-20 mV) and long-lasting afterhyperpolarization (sAHP) (Fig. $2 A$ ). When depolarized from a voltage level positive to about $-55 \mathrm{mV}$, the $\mathrm{BF}$ cholinergic cells displayed single spiking (Fig. $2 B$ ). Hyperpolarizing current pulses applied from a $V_{m}$ positive to $-60 \mathrm{mV}$ always generated a delayed return to baseline, thus revealing TOR (Fig. 2C). In addition, hyperpolarizing current-pulse injection also demonstrated a previously unnoticed though prominent fast inward rectification (Fig. $2 C$ ). In consequence, the instantaneous voltage-current $(V-I)$ relationship of the BF cholinergic cells is markedly nonlinear displaying a pronounced upturn at the negative end of the $V-I$ plot (Fig. 2D).

Finally, a conspicuous electrophysiological feature by which BF cholinergic cells are clearly distinguished is their ability to generate a series of low-threshold rhythmic bursts at a slow frequency $(0.5-3 \mathrm{~Hz})$ both in response to a square long-lasting current pulse and, most distinctively, when slowly depolarized from their resting $V_{m}$. A typical case is illustrated in Figure 3. Note that the cell reacted with two bursts of action potentials when depolarized slowly $(7.6 \mathrm{mV} / \mathrm{sec})$ from its resting $V_{m}(-70$ $\mathrm{mV}$ ) to about $-60 \mathrm{mV}$ (Fig. 3, left). A minor step depolarization from this voltage level then triggered a train of three bursts followed by repetitive single spiking (Fig. 3, right). Generally, the low-threshold bursting did not persist, except in one case (not shown).

\section{Effects of neurotensin on the resting membrane potential and bursting behavior of the BF cholinergic cells}

In all electrophysiologically identified BF cholinergic neurons tested $(n=39)$, bath application of neurotensin (NT; 20-200 $\mathrm{nM}, 1-4 \mathrm{~min})$ resulted in a slow depolarization that was asso- 


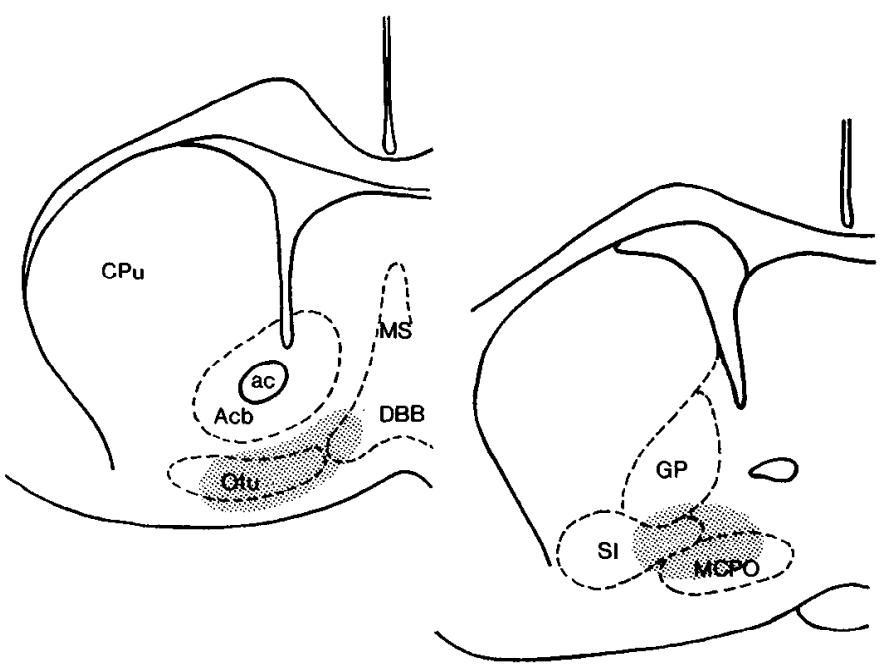

Figure 1. Schematic diagrams of the guinea pig basal forebrain at two different rostrocaudal levels illustrating areas of recording (shaded). Schematics based on camera lucida drawings of incubated tissue slices. Nomenclature is after Gritti et al. (1993). $a c$, anterior commissure; $C P u$, caudoputamen; $A c b$, nucleus accumbens; $M S$, medial septal nucleus; $D B B$, nucleus of the diagonal band of broca; $O T u$, olfactory tubercle; $G P$, globus pallidus; $M C P O$, magnocellular preoptic nucleus; $S I$, substantia innominata. ciated with a decrease in the apparent input conductance $\left(G_{i}\right)$, as was evident when the membrane potential was returned to its resting level by DC hyperpolarization (Fig. $4 A$ ). Analysis of the voltage-current relationship before and after application of NT $(n=5)$ revealed an increase in the slope of the $V-I$ plot that was most prominent at potentials positive to about $-75 \mathrm{mV}$ (Fig. 4C). The control and NT $V-I$ plots typically intersected at $-86.7 \pm 2.3 \mathrm{mV}$, but did not display an obvious crossing point except in one case. The NT-induced decrease in $G_{i}$ was on average $66.6 \pm 22.3 \%$ at membrane potentials from -70 to $-60 \mathrm{mV}$ whereas it only amounted a $14.9 \% \pm 5 \%$ in the voltage range from -75 to $-85 \mathrm{mV}$.

The amplitude of the NT-induced depolarization ranged from 6 to $12 \mathrm{mV}$ and, as in the cell illustrated in Figure $4 A$, was usually large enough $(n=31)$ to bring the cells to firing threshold. Remarkably, the NT action was always associated with a pronounced enhancement of the bursting activity. Note in Figure $4 B$ (enlargement from $A$ ) that the NT-driven firing consisted of prominent bursts of spikes. The burst-enhancement effect of NT is illustrated in more detail in Figure 5 (same cell as in Fig. 4). A typical DC-driven low-threshold response consisting of a spikedoublet followed by a sAHP is shown in Figure $5 \mathrm{~A}$. At the peak of the NT action ( $\sim 3 \mathrm{~min}$ after beginning of NT application) the low-threshold discharge was greatly enhanced and consisted
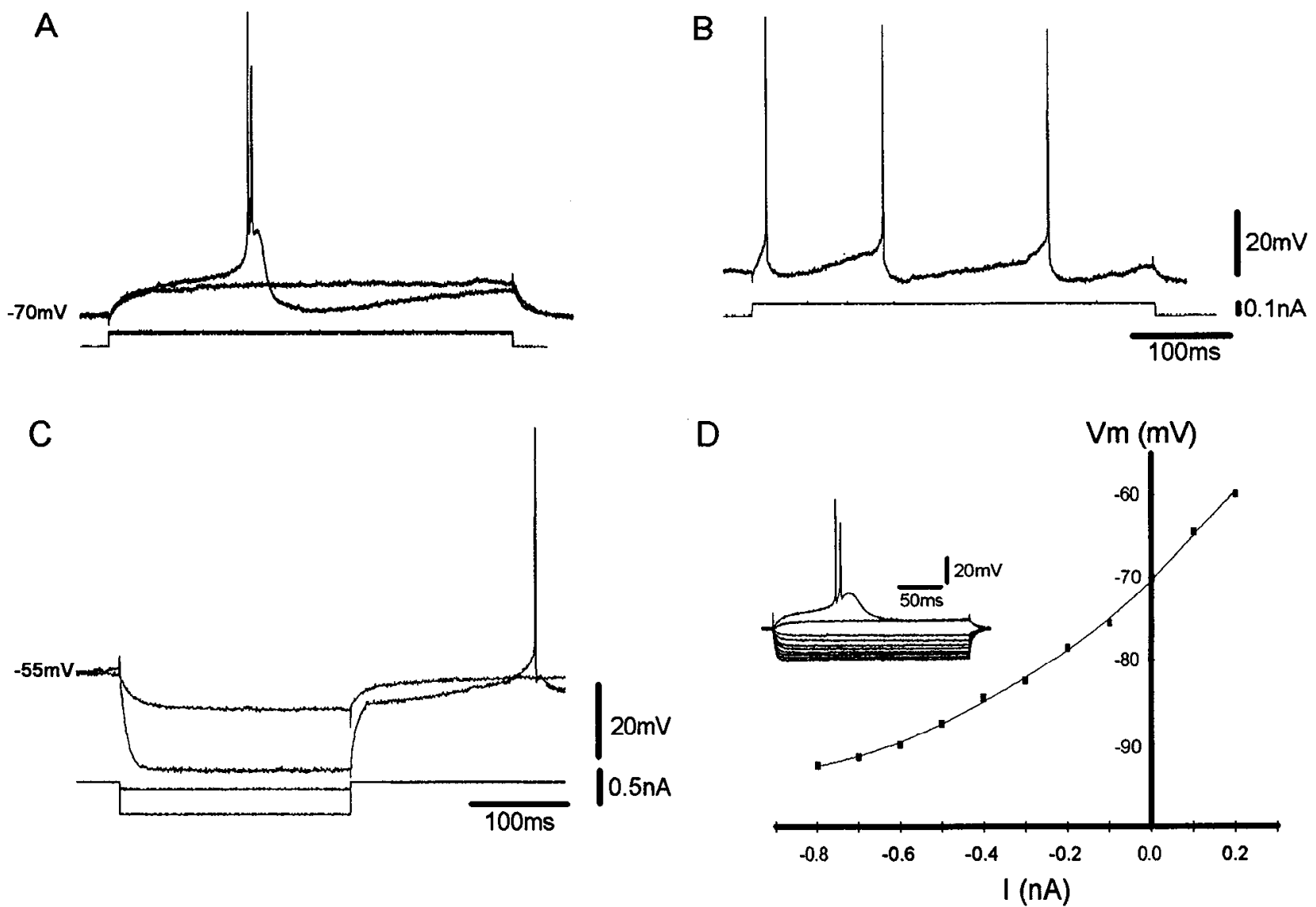

Figure 2. Basic electrophysiological profile of BF cholinergic neurons. $A$ and $B$, Activation of a BF cholinergic neuron by a constant-amplitude depolarizing current pulse from rest $(A)$ and depolarized from rest by about $\sim 15 \mathrm{mV}(B)$. Note that the all-or-none low-threshold burst response elicited from rest became inactivated with depolarization. $C$, Transient outward rectification revealed by the delayed return to baseline at the break of hypcrpolarizing current pulses of increasing amplitude applied from a depolarized membrane potential level. $D$, Voltage-current relationship of $\mathrm{BF}$ cholinergic neurons. Note the prominent upturn at the negative end of the $V / I$ plot demonstrating robust inward rectification. Measurements were taken from the responses to hyperpolarizing-depolarizing current pulses from the cell depicted in the inset (same neuron as $C$ ). 

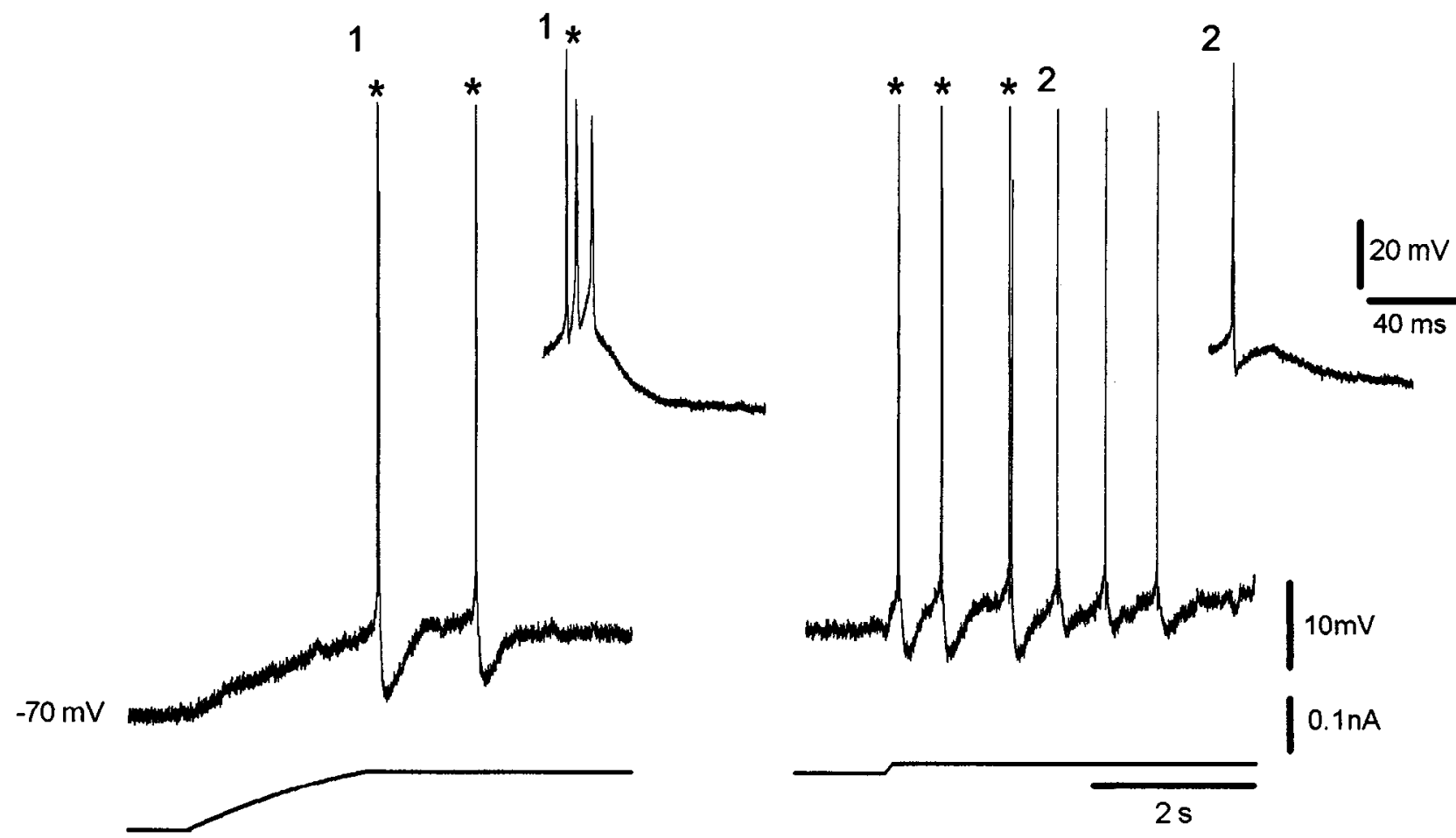

Figure 3. Low-threshold burst responses are characteristically elicited in BF cholinergic neurons by slow-ramp depolarizations. A cholinergic cell was slowly depolarized $(7.6 \mathrm{mV} / \mathrm{sec})$ from its resting level to $\sim-60 \mathrm{mV}$ where it reacted with two bursts of high-frequency action potentials (left). A further minor step depolarization from this voltage level then triggered a series of three more burst responses (asterisks) followed by single spiking (right). Insets 1 and 2 illustrate at an expanded time base the first burst reponse and single spike response, respectively.

of a robust burst of four spikes (Fig. 5B). This effect was associated with a pronounced reduction of the sAHP (Fig. 5C). As illustrated in Figure $5 D-F$, the NT-burst enhancement typically outlasted the depolarizing action by at least $5 \mathrm{~min}$. In control, application of a $0.1 \mathrm{nA}$ depolarizing current pulse from the resting membrane potential $(-70 \mathrm{mV})$ triggers a low-threshold "doublet" and a $0.2 \mathrm{nA}$ pulse drives single spiking (Fig. $5 D$ ). During the NT-induced $G_{i}$ decrease, the largest pulse applied from the same voltage level triggers prominent bursting (Fig. $5 E$ ). Following $10 \mathrm{~min}$ of NT washout, upon return of the membrane potential and $G_{i}$ to their resting levels, the same current pulse still triggers enhanced burst responses (Fig. $5 F$ ), although these are now followed by prominent AHPs. Enhanced bursting was always observed to apparently outlast the membrane potential and $G_{i}$ recovery by $5-20 \mathrm{~min}$ before returning itself to control levels.

The ability of NT to profoundly affect the firing pattern of $\mathrm{BF}$ cholinergic neurons became most apparent after prolonged (3-4 min) applications of the peptide. In most cells tested in this manner (three out of four), and occasionally during shorter applications $(n=3)$, NT caused the development of a very complex periodic bursting pattern (Fig. 6). Figure $6 A$ (al) shows the firing behavior of a BF cholinergic cell immediately following $4 \mathrm{~min}$ superfusion with $100 \mathrm{nM}$ NT in the absence of any holding current. The cell was depolarized by about $10 \mathrm{mV}$ from its resting level $(\sim-67 \mathrm{mV})$ and displayed a repetitive sequence of complex trains of activity at a very low frequency (about 0.2 $\mathrm{Hz}$ ). Each train was initiated by a series of burst responses that appeared to ride on a depolarizing envelope (Fig. 6A, a2) and was terminated by a slow AHP. Figure $6 B$ shows that following 8 min of NT washout the cell had repolarized back toward its resting level. However, at this point a minor DC depolarization $(\sim 10 \mathrm{pA}$; Fig. $6 B$, arrow) triggered the emergence of a lowthreshold rhythmic bursting pattern at a frequency of about 1.5 Iz. That the complex bursting activity was intrinsically generated by the recorded cell and not synaptically driven by network activity was evidenced by two facts: (1) the phenomenon was voltage-dependent, being completely abolished by hyperpolarization (not shown), and (2) similar oscillatory activity was also observed following $\mathrm{Na}^{+}$-conductance blockage with TTX (1 $\mathrm{mm}$ ) (see below).

\section{Specificity of $N T$ actions}

To examine whether the NT responses were due to a specific effect of the peptide, we compared the actions of active and nonactive fragments of the peptide $\left(\mathrm{NT}_{8-13}\right.$ and $\mathrm{NT}_{1-8}$, respectively). As illustrated in Figure 7, the depolarization (Fig. 7A) and burst enhancement actions of NT (Fig. $7 B$ ) were entirely reproduced by bath application of $\mathrm{NT}_{8-13}(50-100 \mathrm{nM}, n=7)$. By contrast, $\mathrm{NT}_{1-8}(n=4)$ failed to induce any detectable effect on the membrane properties of the cholinergic cells (not shown). In addition, bath application of neuromedin $\mathrm{N}(100 \mathrm{nM} ; n=$ 2), a peptide derived from the same precursor molecule as NT and known to bind to the same high-affinity receptor (Checler et al., 1986; Dobner et al., 1987), triggered a membrane potential depolarization associated with a decrease in apparent $G_{i}$ and an enhancement of the bursting behavior of the cholinergic cells (not shown).

\section{Identification of NT's sites of action}

In order to assess whether the observed responses to NT were the result of a direct effect of the peptide on the recorded cells, we used two complementary approaches. First, we analyzed the actions of NT on the membrane properties of BF cholinergic 

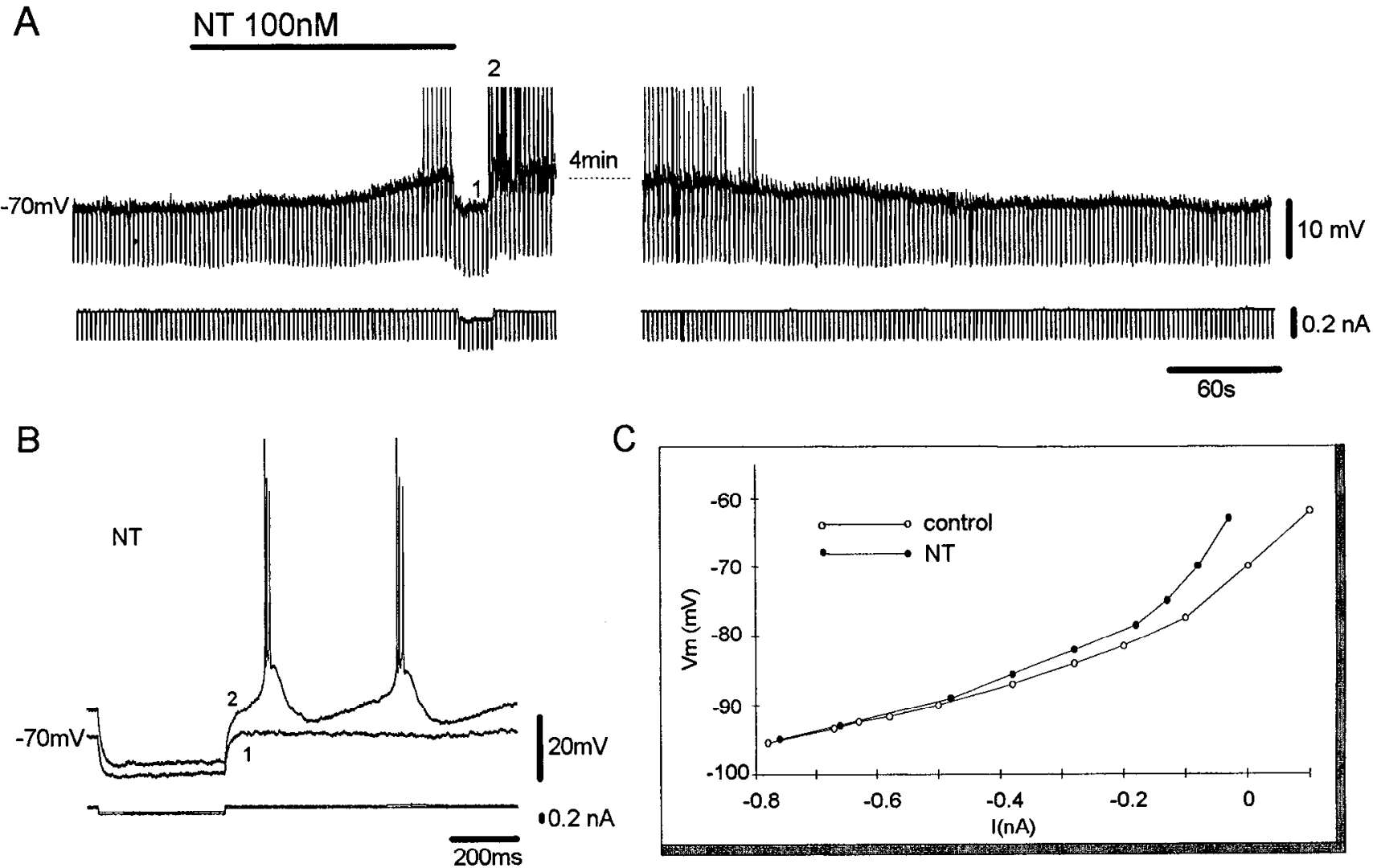

C

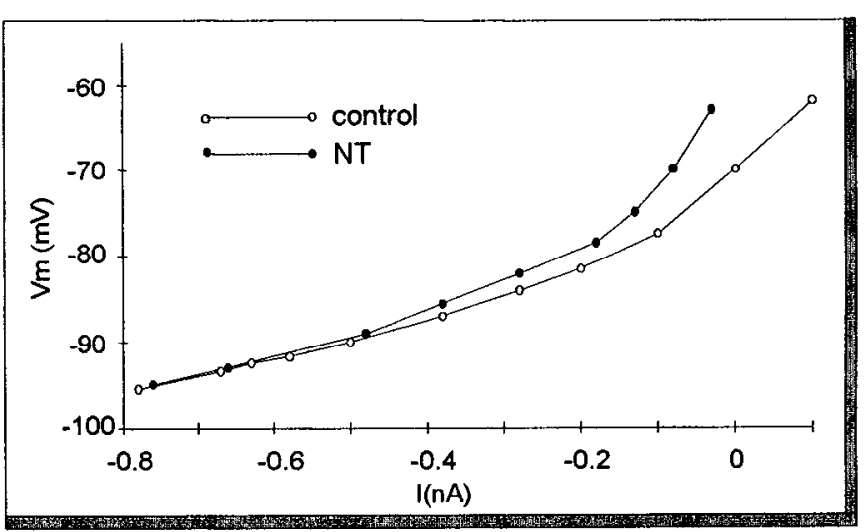

Figure 4. Effects of neurotensin $(N T)$ on membrane potential and apparent input conductance of BF cholinergic neurons. $A$, Application of NT results in a slow and long-lasting ( $>5 \mathrm{~min}$ ) depolarization. Voltage responses to constant amplitude hyperpolarizing current pulses delivered during compensation (by DC current injection) of the NT-induced depolarization illustrate that the depolarization is associated to a decrease in input conductance. B, Prominent rhythmic bursting activity emerges during the NT-induced depolarization. Traces were taken at times 1 and 2 indicated in $A$. C, Voltage-current relationship before (open circles) and during NT-induced depolarization (solid circles). Note that NT caused a voltagedependent increase in input resistance that was most prominent positive to $\sim-75 \mathrm{mV}$. The voltage-current plots were constructed from the steadystate voltage values reached in response to a series of $300 \mathrm{msec}$ hyperpolarizing and depolarizing current pulses applied from the control resting level $(-70 \mathrm{mV})$ and taking into account the holding current in NT.

cells during blockage of synaptic transmission. Second, with the use of a double labeling procedure we investigated whether a fluoresceinylated derivative of the peptide would directly bind to the recorded cells.

Synaptic uncoupling and oscillation. Very much as observed in control Ringer's solution, NT caused a membrane potential depolarization associated to a decrease in apparent $G_{i}$ during synaptic transmission block both with TTX $(1 \mu ; n=9$; Fig. $8 A$ ) and with a low-Ca ${ }^{2+}(0.5 \mathrm{~mm})$, high- $\mathrm{Mn}^{2+}(4 \mathrm{~mm})$ containing solution $(n=4$; not shown). Typically, in the presence of TTX, the depolarization brought the membrane potential of the cells to the threshold for the LTS that underlies the "doublet-burst" responses of the cells (Khateb et al., 1992). Note in Figure 8, $A$ and $B$, that prominent LTSs develop at the break of the test hyperpolarizing current pulses applied during the NT-induced depolarization (Fig. $8 A$, arrow; $B$ ). The LTS enhancement is illustrated in more detail in Figure $8 C-E$ (same cell as Fig. $8 A$ ). Figure $8 C$ illustrates the characteristic LTS evoked by constant current-pulse depolarization from the resting membrane potential of the cell $(-70 \mathrm{mV})$ in control Ringer's solution. In Figure $8 D$, a LTS is evoked from the same membrane potential during the NT-induced $G_{i}$ decrease. The control and NT LTSs have been superimposed in Figure $8 E$. Note the prominent increase in the amplitude, as well as in the rate of rise and duration of the LTS during NT.
A diversity of mechanisms may be responsible for the LTS enhancement by NT. Since BF cholinergic neurons possess a prominent TOR that develops at a similar voltage range to that of LTS activation (Fig. 2C), a reduction of this rectification by NT may account, at least in part, for the LTS enhancement. As illustrated in Figure $9 A-C$, in all cases NT indeed caused a substantial reduction of the delayed return to baseline at the break of hyperpolarizing current pulses that is consistent with an NT-induced decrease of the transient outward rectifier.

The membrane oscillatory behavior induced by NT (Fig. 6) appeared to be dependent on the activation of $\mathrm{Ca}^{2+}$ conductances but not $\mathrm{Na}^{+}$conductances, since it was not present during $\mathrm{Ca}^{2+}$-conductance block with $\mathrm{Mn}^{2+}$ but was always observed in the presence of TTX (Fig. 10). Figure 10 $\mathrm{A}$ illustrates bursting oscillations in a BF cholinergic cell during the peak response to a 1 min application of NT (100 nM). The peptide had produced a subthreshold depolarization of the cell to about $-60 \mathrm{mV}$. A small DC depolarization from this voltage level (Fig. 10 $A$, arrow in the current trace) triggered the complex bursting pattern. Following NT washout $(20 \mathrm{~min})$ and during $\mathrm{Na}^{+}$-conductance block with TTX $(1 \mu \mathrm{M})$, the peptide $(100 \mathrm{nM})$ was reapplied for $1.5 \mathrm{~min}$. Figure $10 \mathrm{~B}$ illustrates the voltage behavior of the cell in response to membrane potential manipulation during the peak of the NT action. At the beginning of the trace, the cell was held at about $-65 \mathrm{mV}$ by hyperpolarizing constant current 

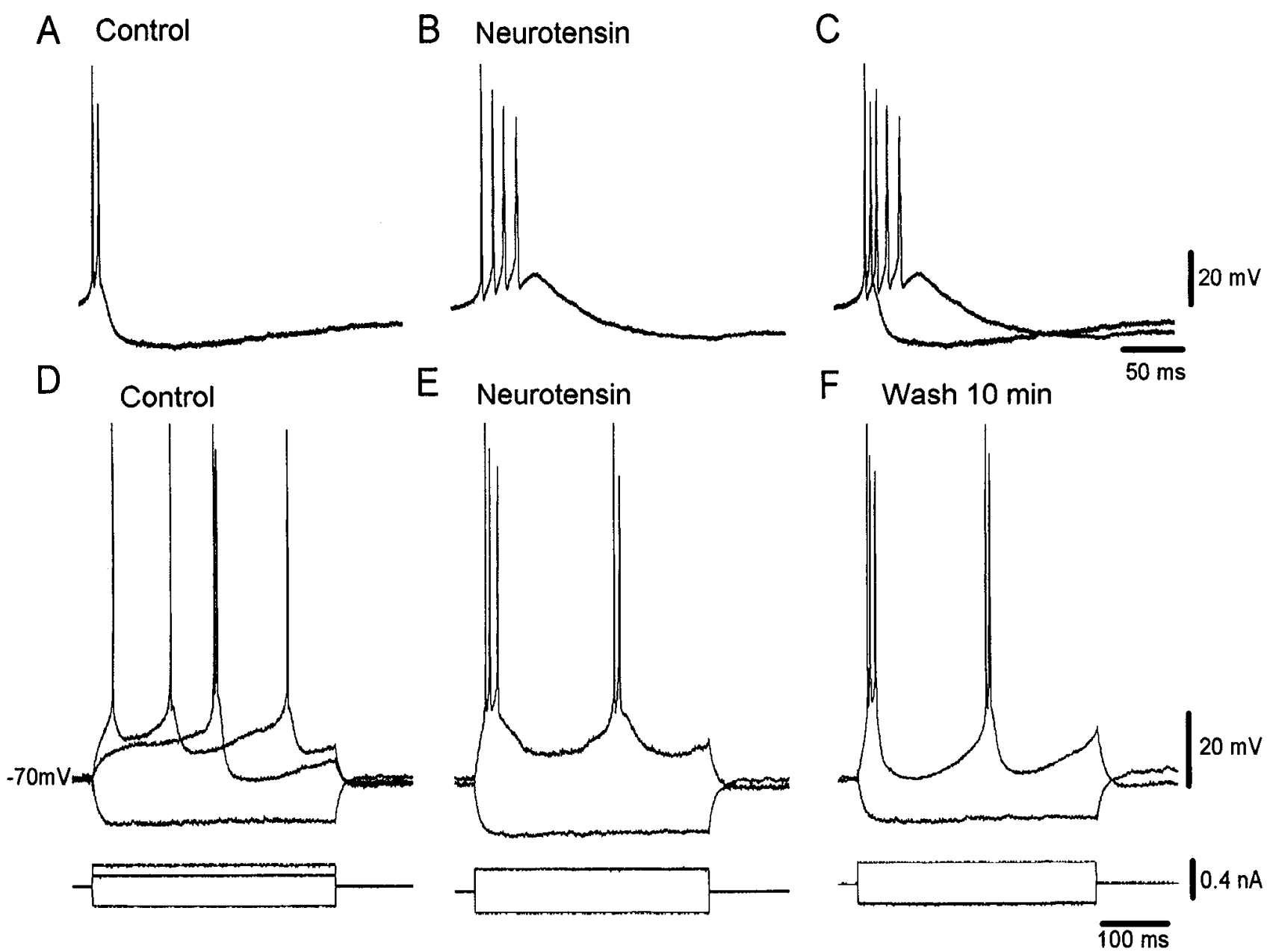

Figure 5. Fffects of NT on the low-threshold burst responses. Same neuron as in Figure 4. $A$ and $B$, Low-threshold burst before $(A)$ and during $(B)$ NT application. $C$, Superimposition of $A$ and $B$. Note that NT substantially blocked the slow afterhyperpolarization (sAHP) and doubled the number of spikes per burst. $D$ and $E$, Voltage responses to depolarizing and hyperpolarizing current pulses before $(D)$ and during NT action $(E)$ applied from the same voltage level. $F$, Superimposition of $D$ and $E$. Note that the same depolarizing current pulse that triggered single spiking in control Ringer's $(D)$ elicited prominent bursts during NT depolarizing action $(E)$ and that the burst enhancement outlasted the depolarizing effect $(F)$.

injection that was then slowly and completely released (two arrows). The depolarization triggered two prominent LTSs before the cell became silent at its resting membrane potential. From this voltage level, a minor DC depolarization (asterisk) triggered the emergence of a rhythmic oscillatory phenomenon. At steady state (Fig. 10B, right half of trace), the oscillation consisted of rather slow (300-800 msec in duration), $10-15 \mathrm{mV}$ regenerative events arising from a membrane potential of about $-45 \mathrm{mV}$ and separated by a low-amplitude slow AHP. The frequency of the oscillatory event $(\sim 0.2 \mathrm{~Hz})$ closely matched that of the complex bursting during NT action in the absence of TTX (Fig. 10A). It must be noted that the emergence of the persistent rhythmic oscillatory activity required the application of NT and disappeared following $10 \mathrm{~min}$ of NT washout (not shown).

Confocal microscopic identification of NT targets. To provide further evidence for a direct effect of NT upon recorded cells, we substituted for the native peptide a fluoresceinylated derivative ( $N$ - $\alpha$-fluoresceinyl thiocarbamyl-\{Glu' $\}$ NT; fluo-NT) known to bind with the same selectivity and affinity as NT to central high-affinity NT receptors (Faure et al., 1992). We then followed the fate of fluo-NT by CLSM after filling the recorded cells with biocytin.

In a first set of experiments designed to confirm the biological activity of fluo-NT, the effects of the fluorescent peptide on electrophysiologically identified BF cholinergic cells were compared to those of native NT (Fig. 11). Figure $11 A$ shows the membrane voltage behavior of a $\mathrm{BF}$ cell during a slow, manually driven, ramp depolarization in control Ringer's solution. The neuron displayed the unequivocal voltage behavior of $\mathrm{BF}$ cholinergic cells (Fig. 3) by reacting with a pair of bursts of spikes each followed by a deep AHP (Fig. 11 $\mathrm{A}$, asterisks) when depolarized to about $-55 \mathrm{mV}$. Bath application of fluo-NT (100 $\mathrm{nM}, 1 \mathrm{~min}$ ) triggered a membrane potential depolarization of about $15 \mathrm{mV}$ associated with a decrease in apparent $G_{i}$ (Fig. $11 B$ ). This depolarization brought the cell to firing threshold and caused the development of a persistent rhythmic bursting pattern (Fig. 11B,C). Fluo-NT induced a prominent enhancement of the individual bursts and a concomitant block of the sAHP (Fig. 11C). Similar responses were obtained in all cells tested with fluo-NT $(n=8)$ proving that the fluoresceinylated derivative had the same biological activity as native NT. 

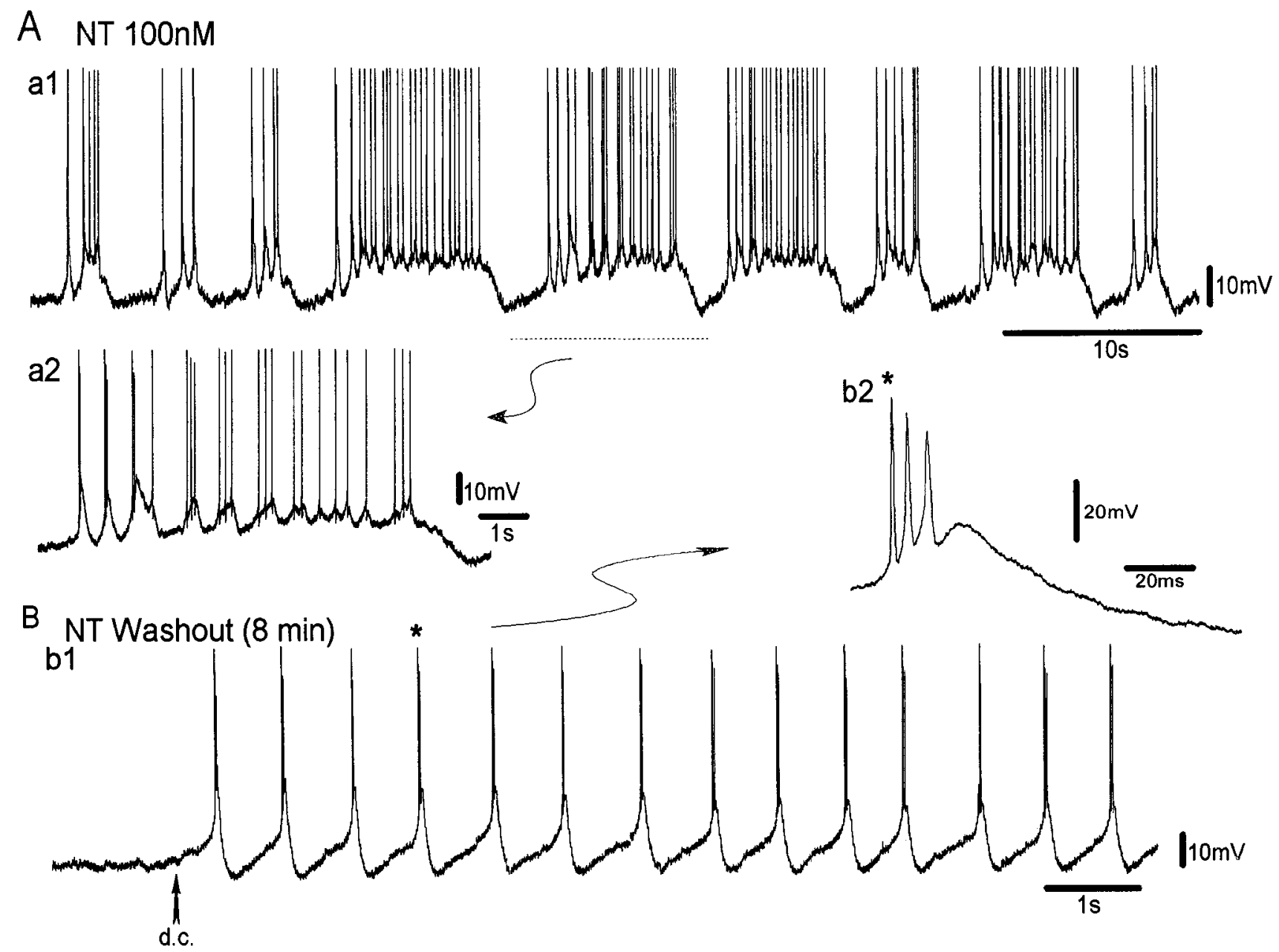

Figure 6. NT induces complex spindle-like bursting sequences. Same neuron as Figure 3. $A$, Complex bursting behavior immediately following 4 min superfusion with $100 \mathrm{nM} \mathrm{NT}$. The burst sequence signaled by a dotted line in al is illustrated at an expanded time base in $a 2$. $B$, Rhythmic bursting pattern triggered by DC depolarization from the resting level $(-67 \mathrm{mV})$ after $8 \mathrm{~min}$ of NT washout. The burst event signaled by an asterisk in $b 1$ is illustrated at an expanded time base in $b 2$.

CLSM examination of brain slices fixed 45 min after 1-3 min bath application of 20-100 nм fluo-NT revealed the presence of numerous fluorescent neuronal perikarya distributed throughout the medial septum, diagonal band of broca, and substantia innominata (Fig. 12a). These fluo-NT-labeled cells were large and multipolar in shape, in keeping with published descriptions of BF cholinergic neurons (Armstrong et al., 1983). A few also exhibited prominent fluorescent labeling of one or several proximal dendritic processes (Fig. 12b). Serial optical sectioning of fluo-NT-labeled neurons indicated that the bulk of the fluorescent labeling was located inside the perikaryon of the cell rather than on the cell surface (Fig. 12a,b). At high magnification of $10-\mu$ m-thick optical sections scanned at high resolution, the label was seen to be concentrated within small (1-2 $\mu \mathrm{m}$ in diameter) granular "hot spots" reminiscent of endocytic vesicles (Fig. 12a,b). Although many of these fluorescent granules approximated the nuclear membrane, few if any were actually detected inside the nucleus.

Cholinergic cells intracellularly injected with biocytin and subsequently treated with streptavidin-Texas red exhibited intense fluorescent labeling of their perikarya and dendritic arbor (Fig. 12c,e). All of these biocytin-filled cells $(n=5)$ were also responsive to and stained positively for fluo-NT (Fig. 12d,f). Merging of the two confocal images confirmed the colocalization of the two markers.

\section{NT actions on other electrophysiologically distinct BF neurons}

A significant proportion of recorded neurons (36\%) displayed an electrophysiological profile distinct from that of the cholinergic cell type we have considered so far. The electrophysiology of this second group of cells was nevertheless heterogeneous. One category (Mühlethaler et al., 1992) has recently been found to correspond to fast-spiking non-ChAT-immunoreactive neurons (to be described in detail elsewhere; A. Alonso, A. Khateb, P. Fort, B. E. Jones, and M. Mühlethaler, unpublished observations). We tested the effects of bath application of NT (100 $\mathrm{nM}, 2 \mathrm{~min}$ ) in four of these noncholinergic neurons. No significant effect on the membrane properties of these cells were observed.

We also tested NT on another distinct group of $\mathrm{BF}$ neurons (Fig. 13). Similarly to the bursting BF cholinergic cells that we have dealt with above, these neurons $(n=15)$ also displayed prominent TOR and fast inward rectification. However, in contrast to the bursting BF cholinergic cells, this category of neurons 

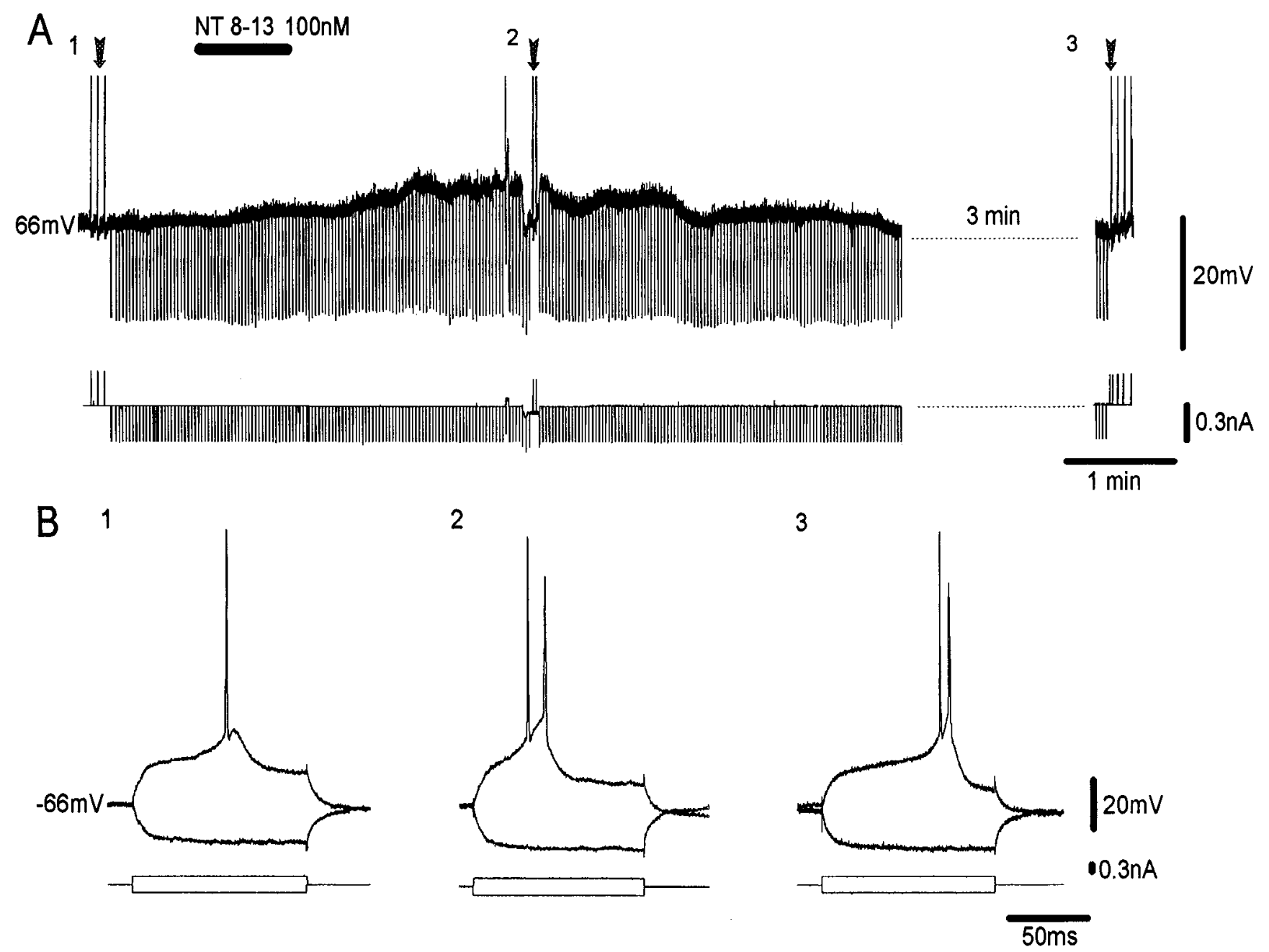

Figure 7. Specificity of NT action. A, Application of NT 8-13, results in membrane depolarization associated to a decrease in input conductance. $B$, Voltage responses to depolarizing and hyperpolarizing current pulses at times 1,2 , and 3 indicated in $A$. Note that similarly to NT, NT $8-13$ also enhanced the low-threshold discharge.

did not display a voltage-dependent switch in firing pattcrn. Firing always consisted of single broad spikes followed by a large-amplitude slow AHP with no depolarizing afterpotential (Fig. 13A). NT (100 nM) was bath applied to five of these cells. All of them responded with a robust $(>10 \mathrm{mV})$ membrane potential depolarization associated with a decrease in apparent $G_{i}$ that sustained repetitive firing (Fig. 13B). The slow AHP was largely abolished by NT (Fig. 13C) though burst firing was never elicited by NT in these cells.

\section{Discussion}

The present results indicate robust neuromodulatory actions of NT on BF cholinergic neurons. NT caused membrane depolarization associated with a decrease in apparent $G_{i}$ and, most significantly, affected several membrane properties leading to the emergence of a remarkable rhythmic bursting pattern. These effects were direct since NT also induced $V_{m}$ depolarization and oscillation during synaptic uncoupling. Moreover, confocal microscopic examination of the responsive cells after fluo-NT application and intracellular biocytin labeling demonstrated that they had systematically bound and internalized the peptide.

\section{NT internalizalion}

Confocal microscopic experiments indicated that fluo-NT had selectively associated with a selective subset of BF neurons. Demonstration that these cells were cholinergic was recently provided by double labeling experiments showing that virtually all fluo-NT-labeled BF neurons were ChAT immunopositive (M. P. Faure, A. Alonso, D. Nouel, G. Gaudriault, M. Dennis, J. P. Vincent, and A. Beaudet, unpublished observations). These results conform with previous EM autoradiographic experiments that had shown NT receptors to be associated with the plasma membrane of BF cholinesterase-positive cells (Szigethy et al., 1990). A major finding of the present study, however, was that fluo-NT molecules were detected within the cytoplasm of perikarya and dendrites of the cholinergic cells. This implies that fluo-NT molecules had been internalized subsequently to their association with and activation of cell surface receptors. NT internalization has previously been documented in primary neuronal cultures (Mazella et al., 1991; Vanisberg et al., 1991; Chabry et al., 1993), where it has been found to be both ligand induced and receptor mediated (Mazella et al., 1991; Vanisberg et al., 1991; Chabry et al., 1993). The granular pattern of intra- 


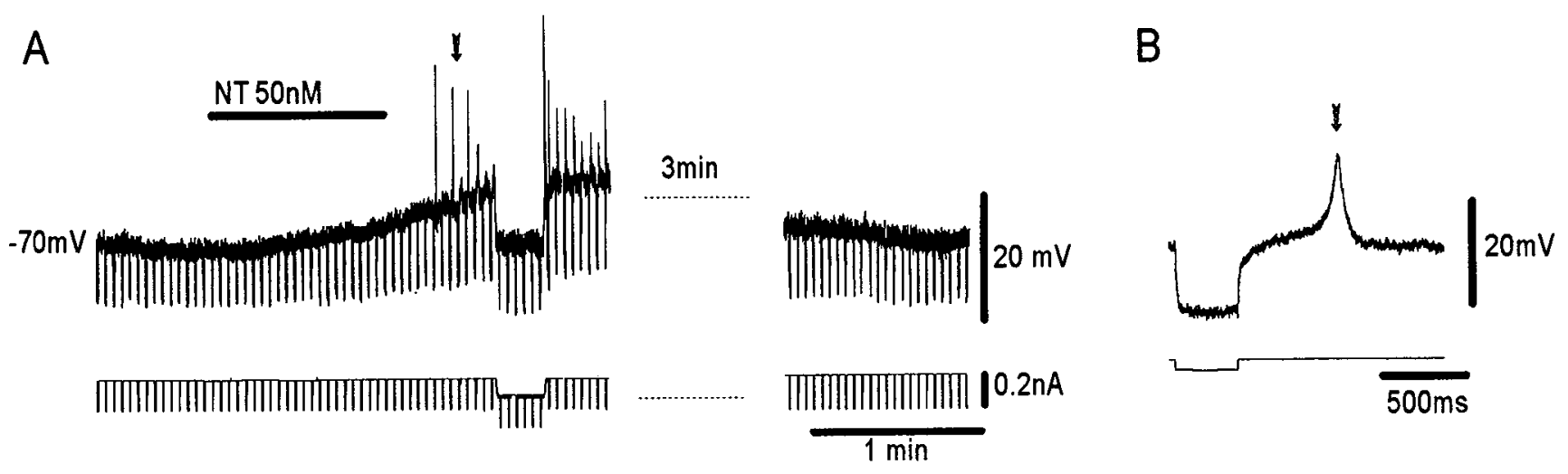

C Control
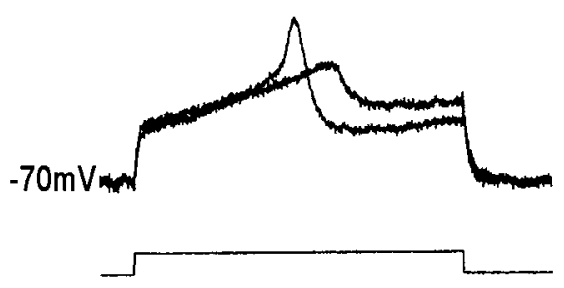

D NT

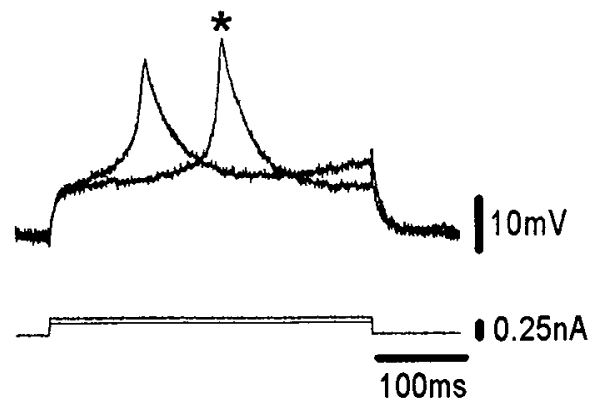

$E$

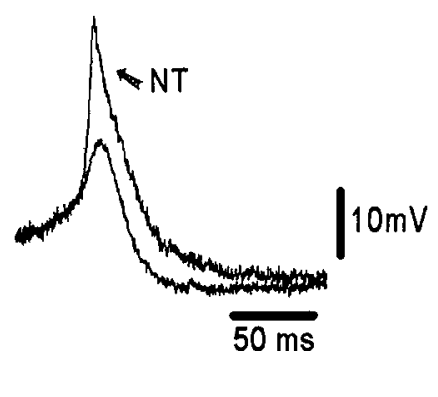

Figure 8. NT actions persist during $\mathrm{Na}^{+}$-conductance block. $A$. Bath application of NT in the presence of TTX ( $\left.1 \mu \mathrm{M}\right)$ causes membrane depolarization associated to a decrease in input conductance. $B$, Rebound low-threshold spike (LTS) at the break of a test hyperpolarizing current pulse during the NT-induced depolarization (arrow in $A$ ). $C$ and $D$, LTSs evoked by depolarizing current pulses before (C) and during NT action $(D)$. $E$, Superimposition of the LTSs in $C$ and $D$ (asterisk). Note the enhancement in the amplitude and duration of the LTS induced by NT.

cellular ligand distribution observed here lends further support to the concept of receptor-mediated event, as receptor-mediated endocytosis has been shown to be subserved by the endosomal compartment (Hopkins et al., 1990; Parton et al., 1992).

\section{$N T$ actions and bursting mechanism in BF cholinergic cells}

Previous studies have shown NT to exert direct excitatory effects on a variety of CNS neurons (Nicoll, 1978; Sawada et al., 1980;
A
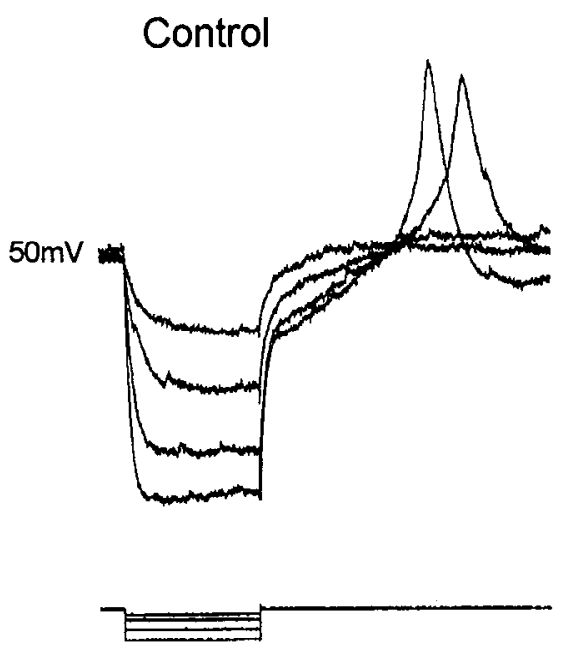

B
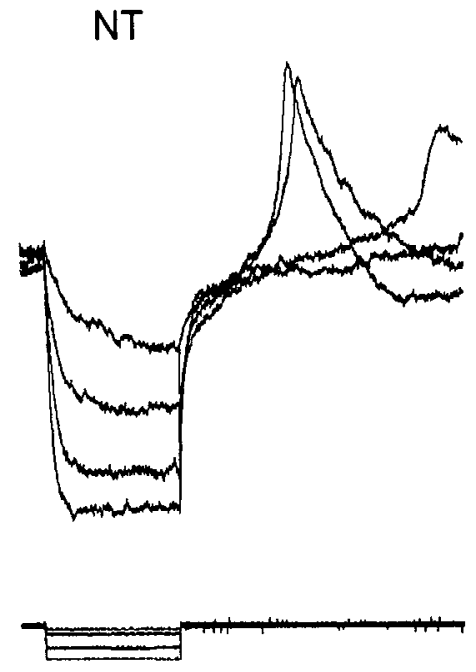

C

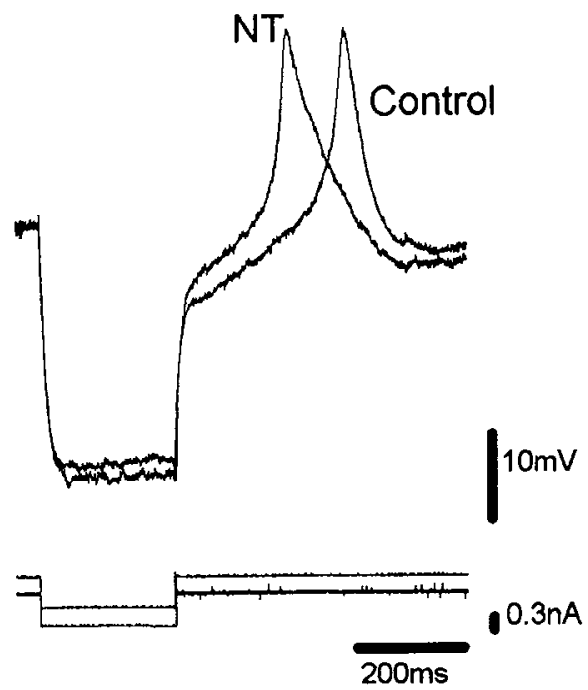

Figure 9. NT blocks transient outward rectification. $A$ and $B$, Voltage responses to hyperpolarizing current pulses before $(A)$ and during bath application of NT $(100 \mathrm{nM})(B)$. $C$, Superimposition of the responses to the largest current pulses in $A$ and $B$. Note the pronounced reduction in the delayed return to baseline at the break of the current pulses during NT action. 


\section{NT 100nM}

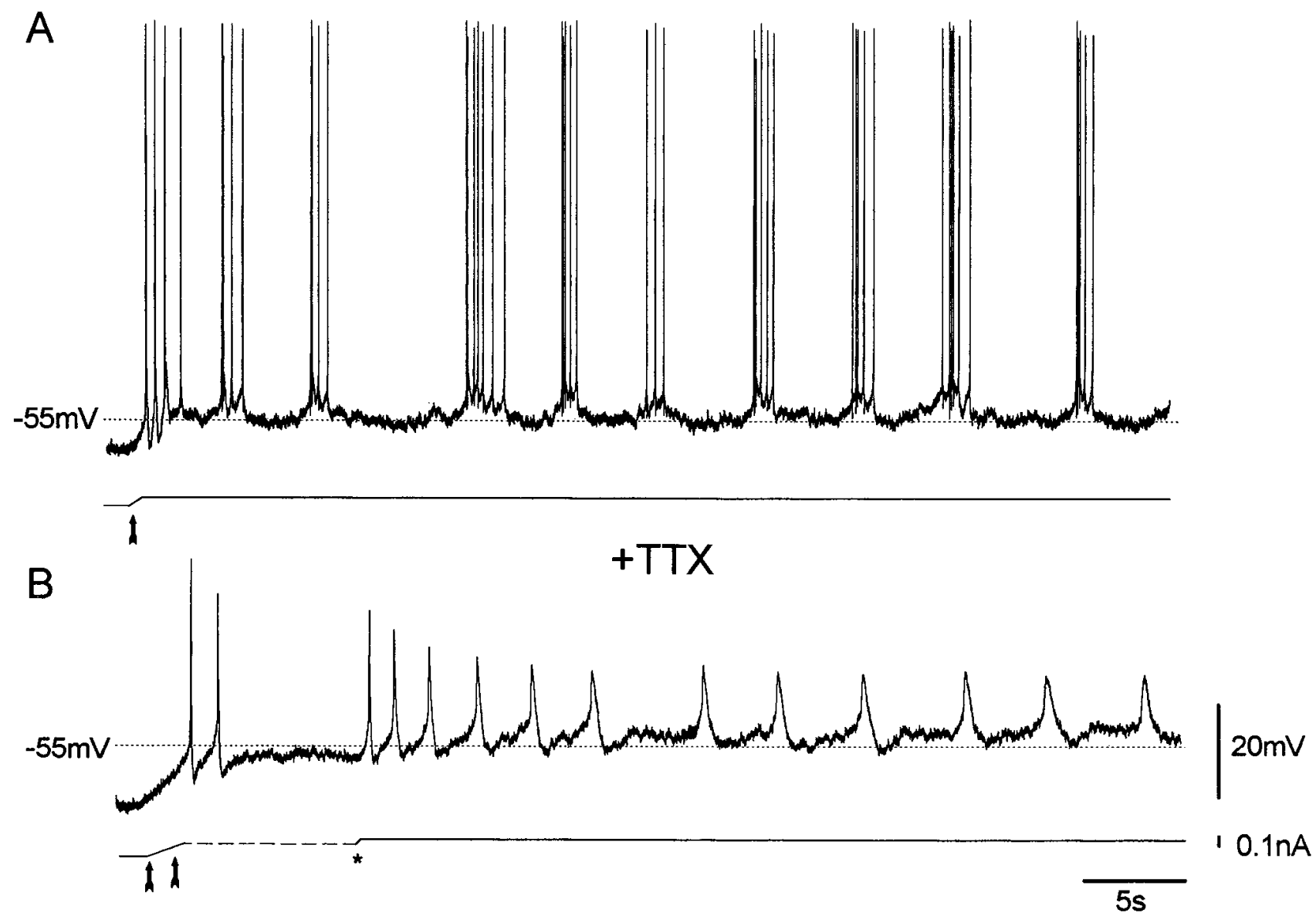

Figure 10. NT induces rhythmic membrane potential oscillations after $\mathrm{Na}^{+}$-conductance block. $A$, Complex bursting pattern during the peak response to a $1 \mathrm{~min}$ application of NT $(100 \mathrm{nM})$. Bursting oscillatory activity emerged following DC depolarization (arrow) from the resting level to $\sim-50 \mathrm{mV}$. Note that the intertrain membrane potential trajectories are always positive to $-55 \mathrm{mV}$ (dotted line) with the exception of sAHPs following the two initial discharges. $B$, Same neuron. Rhythmic membrane oscillatory activity during the peak response to NT (100 nM, 1 min) applied 20 min after beginning of washout from $A$ and during $\mathrm{Na}^{+}$-conductance block with TTX $(1 \mu \mathrm{M})$. Two LTSs are evoked at the beginning of the trace upon release of DC hyperpolarization ( $t w o$ arrows). A minor DC depolarization from the resting level (asterisk) then triggered rhythmic persistent membrane potential oscillations at about the same frequency as in $A$. The broken line in the current trace indicates the period of 0 holding current.

Stanzione and Zieglgansberger, 1983; Pinnock, 1985; Behbehani et al., 1987; Audinat et al., 1989; Seutin et al., 1989; see Shi and Bunney, 1992, for recent review). Moreover, a recent report on the effects of NT on BF cholinergic neurons in primary cell culture described a $G_{i}$ decrease accompanied by an inward current reflecting membrane depolarization (Farkas et al., 1992).

Our analysis of the $V-I$ relationship beforc and after NT application revealed that the control and NT $V-I$ plots intersected, though they did not always crossed, at $-87 \mathrm{mV}$, suggesting that the NT-induced depolarization could be due to a decrease in a $\mathrm{K}^{+}$conductance (Farkas et al., 1992). We also observed that the NT action was at least partially voltage dependent since the $G_{i}$ decrease was larger at potentials positive to $-70 \mathrm{mV}$. This may reflect a voltage-dependent component in the potential $\mathrm{K}^{+}$outward current blocked by NT. However, other depolarizing mechanisms reported for some peptides acting on CNS neurons (e.g., activation of a voltage-dependent and TTX-insensitive $\mathrm{Na}^{+}$current; Raggenbass et al., 1991) may have participated in the NT-induced depolarization.

In addition to the effects on $V_{m}$ and $G_{i}$, NT also acted on other electrophysiological features of the BF cholinergic cells. Remarkably, the characteristic $\mathrm{Ca}^{2+}$-dependant low-threshold doublet-discharge of these cells (Khateb et al., 1992) became a much longer burst of three to five spikes under NT. This burst enhancement was associated with a pronounced reduction of the concomitant sAHP, suggesting that NT acted by blocking a $\mathrm{Ca}^{2+}$-dependent potassium conductance (Hille, 1992). Interestingly, enhanced bursting was still present after recovery of the sAHP, $V_{m}$, and $G_{i}$. This suggests that the NT burst enhancement is in part independent of its effects on $V_{m}$ and $G_{i}$.

BF cholinergic neurons are also endowed with TOR that was reduced by NT. This effect facilitated membrane repolarization and, thus, the activation of the inward current(s) underlying the bursting behavior. Our observation that NT induced an increase in the amplitude and duration of the LTS may have resulted from such NT action (McCormick, 1991).

The modulation by NT of multiple membrane conductances promoted rhythmic bursting and the development of complex spindle-like bursting sequences. In discussing these data, it helps to consider the low-threshold bursting properties of thalamo- 

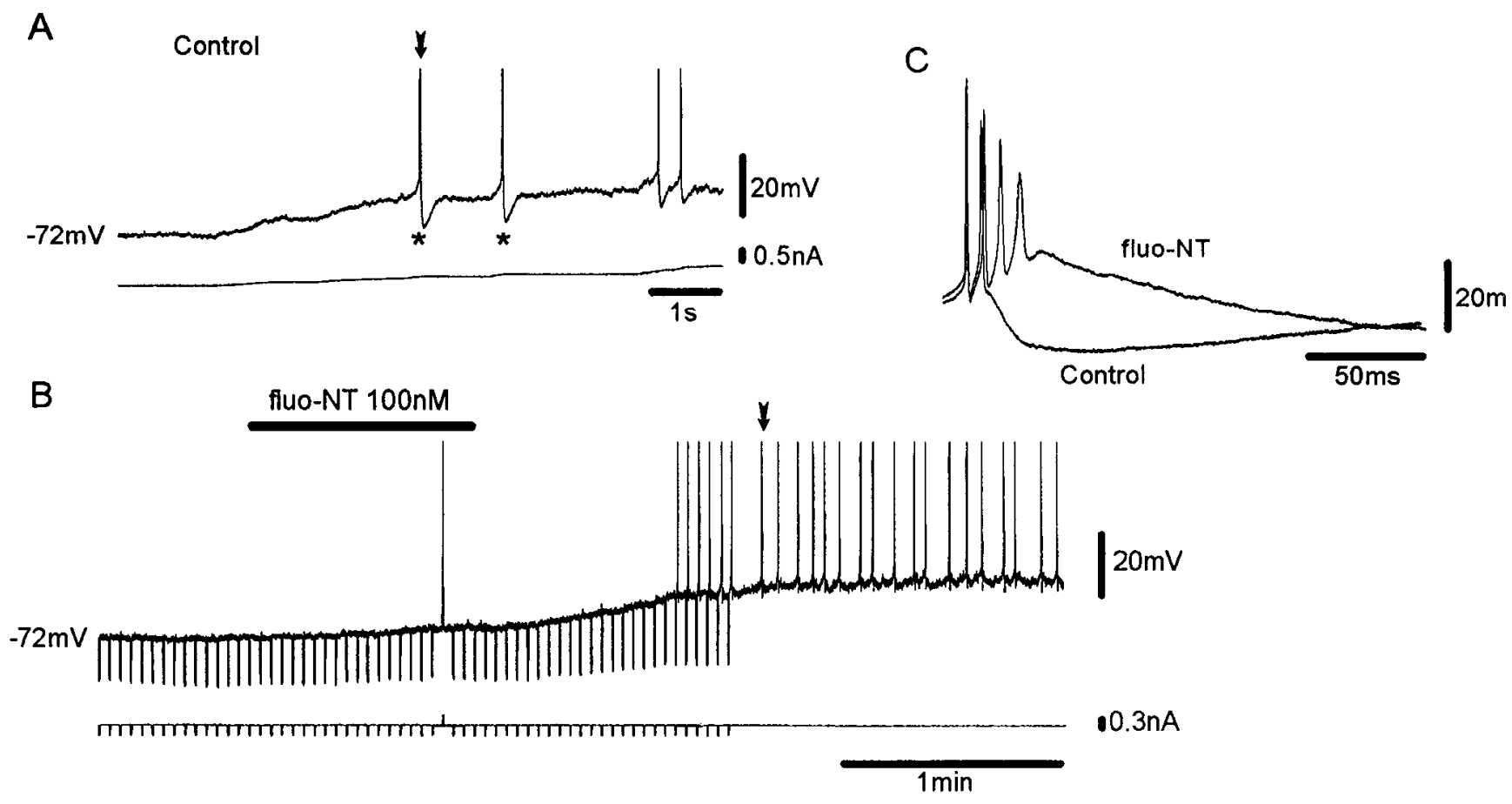

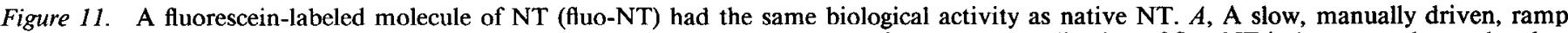

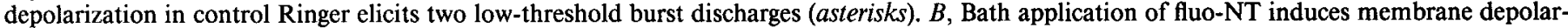

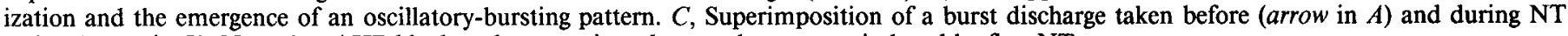
action (arrow in $B$ ). Note the s $\Lambda$ HP block and concomitant burst enhancement induced by fluo-NT.

cortical relay cells (TCs) (Jahnsen and Llinás, 1984a,b; Coulter et al., 1989; Crunelli et al., 1989; McCormick and Pape, 1990; McCormick and Huguenard, 1992). The LTS of TCs is generated by a low-threshold $\mathrm{Ca}^{2+}$ current $\left(I_{t(\mathrm{tc})}\right)$ that activates positive to $-70 \mathrm{mV}$ with complete inactivation at $-60 \mathrm{mV}$ (Coulter et al., 1989). $I_{i(\mathrm{cc})}$ rate of inactivation is fast so that membrane depolarization at a slow rate $(<30 \mathrm{mV} / \mathrm{sec})$ fails to generate a LTS (Crunelli et al., 1989). In some TCs, rhythmic bursting depends on the interplay of $I_{t(\mathrm{tc})}$ and a time-dependent inward rectifier $\left(I_{h} ;\right.$ McCormick and Pape, 1990). Because of the biophysical properties of $I_{i(\mathrm{tc})}$ and $I_{h}$, TCs oscillate at $V_{m}$ values negative to $-70 \mathrm{mV}$.

BF cholinergic neurons' oscillatory-bursting mechanism presents clear differences from that of TCs. First, the LTS in BF cholinergic neurons can be triggered from a $V_{m}$ of $-60 \mathrm{mV}$ (where $I_{t(\text { ic) }}$ inactivation is complete) and by very slow ramp depolarizations (incompatible with the slow inactivation kinetics of $\left.I_{t(\mathrm{tc})}\right)$. Also, BF cholinergic neurons display robust fast inward rectification at $V_{m}$ values negative to $-70 \mathrm{mV}$. This makes electroresponsiveness difficult at those voltages where TCs oscillate.

Thus, oscillatory-bursting in BF cholinergic cells may be driven by a different type of $\mathrm{Ca}^{2+}$ current than in TCs (Huguenard and Prince, 1992; Huguenard et al., 1993). Indeed, a recent whole-cell, patch-clamp study of dissociated BF cholinergic neurons from early postnatal rats (Allen et al., 1993) describes a prominent low-threshold transient $\mathrm{Ca}^{2+}$ current with both an unusually positive threshold of activation $(-55 \mathrm{mV})$ and halfinactivation potential $(-50 \mathrm{mV})$, and slow inactivation kinetics $\left(t_{d} \sim 80 \mathrm{msec}\right.$ at $\left.-50 \mathrm{mV}\right)$. These neurons also display more sustained $\mathrm{Ca}^{2+}$ currents at a threshold $10-20 \mathrm{mV}$ more positive than the low-threshold current (see also Klink et al., 1993).
The NT-induced depolarization brought the $V_{m}$ of the cholinergic cells from its negative resting level $(\sim-68 \mathrm{mV})$, into the range of activation of the $\mathrm{Ca}^{2+}$ currents. Persistent rhythmic oscillations of prolonged bursts probably developed as a result of enhanced $\mathrm{Ca}^{2+}$-mediated potentials, an effect likely caused by, at least, a reduction of outward $\mathrm{K}^{+}$currents. During NT maximal responses, oscillations occurred at potentials well positive to $-55 \mathrm{mV}$ and frequently shaped into repetitive spindlelike trains of bursting activity with minimal sAHPs. This result indicates that the high-threshold $\mathrm{Ca}^{2}$ currents largely contributed to the maintenance of NT-induced complex oscillations.

In addition to its effects on bursting BF ncurons, NT also depolarized another distinct group of BF neurons that had the electrophysiological characteristics of those identified as cholinergic cells by Markram and Segal (1990) in the medial septumdiagonal band complex (see also Griffith and Mathews, 1986; Griffith, 1988). Indeed, all our nonbursting NT-responsive cells were recorded within the horizontal limb of the diagonal band. These dala suggest the existence of different BF cholinergic "subsystems."

In agreement with the selective association of NT receptors with cholinergic cells in the BF (Szigethy et al., 1989, 1990), we found that NT had no detectable effect on those cells that electrophysiology corresponded to ChAT immunonegative neurons (Mühlethaler et al., 1992; A. Alonso, A. Khateb, P. Fort, B. E. Jones, and M. Mühlethaler, unpublished observations).

\section{Functional implications}

There is substantial evidence that BF cholinergic neurons promote cortical arousal (for review, see Buzsàki et al., 1988; Vanderwolf, 1988; Steriade and McCarley, 1990). One would expect, therefore, these cells to increase their firing rates during cortical 

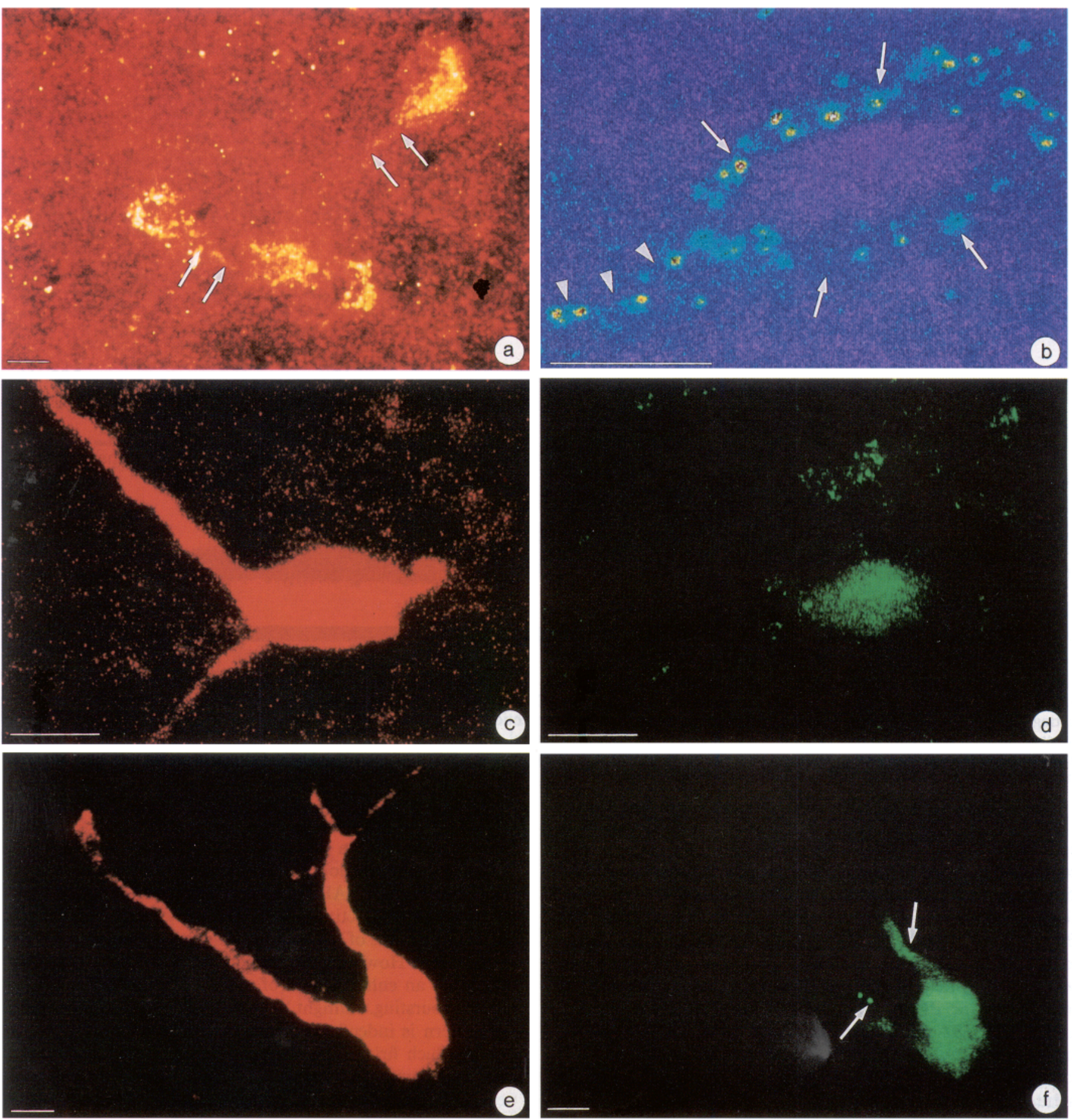

Figure 12. Confocal microscopic images of slices of the basal forebrain incubated with 20-50 nм fluo-NT. $a$ and $b$, Optical sections $10 \mu \mathrm{m}$ thick. In $a$, several large, multipolar neurons show dense accumulations of internalized ligand. Note the granular appearance of the label, and its presence in proximal dendritic processes (arrows). In $b$, a large neuron exhibits intensely labeled endosome-like particles. Pseudocolor rendition, with areas of intense labeling in yellow and zones of low labeling in blue-purple. Labeled particles are distributed throughout the cytoplasm of the perikaryon (arrows) and inside a dendritic process (arrowheads). Note the complete sparing of the nucleus. $c$ and $f$, Biocytin-injected cells double labeled with fluo-NT. Composite images reconstructed from 25 sequential $0.12-\mu$ m-thick optical sections. $c$ and $e$, Biocytin, revealed with streptavidin-Texas red, pervades the entire cytoplasm and dendritic arbor of two substantia innominata neurons identified electrophysiologically as cholinergic. $d$ and $f$, The same two cells are seen to have internalized fluo-NT when imaged in the FITC emission spectrum. Note that the ligand is mainly concentrated in the perikaryon but that some is also visible at the emergence of the lower dendrites (arrows). The label appears more homogeneously distributed than in $a$ and $b$ because of the imaging process. Scale bars, $10 \mu \mathrm{m}$. 


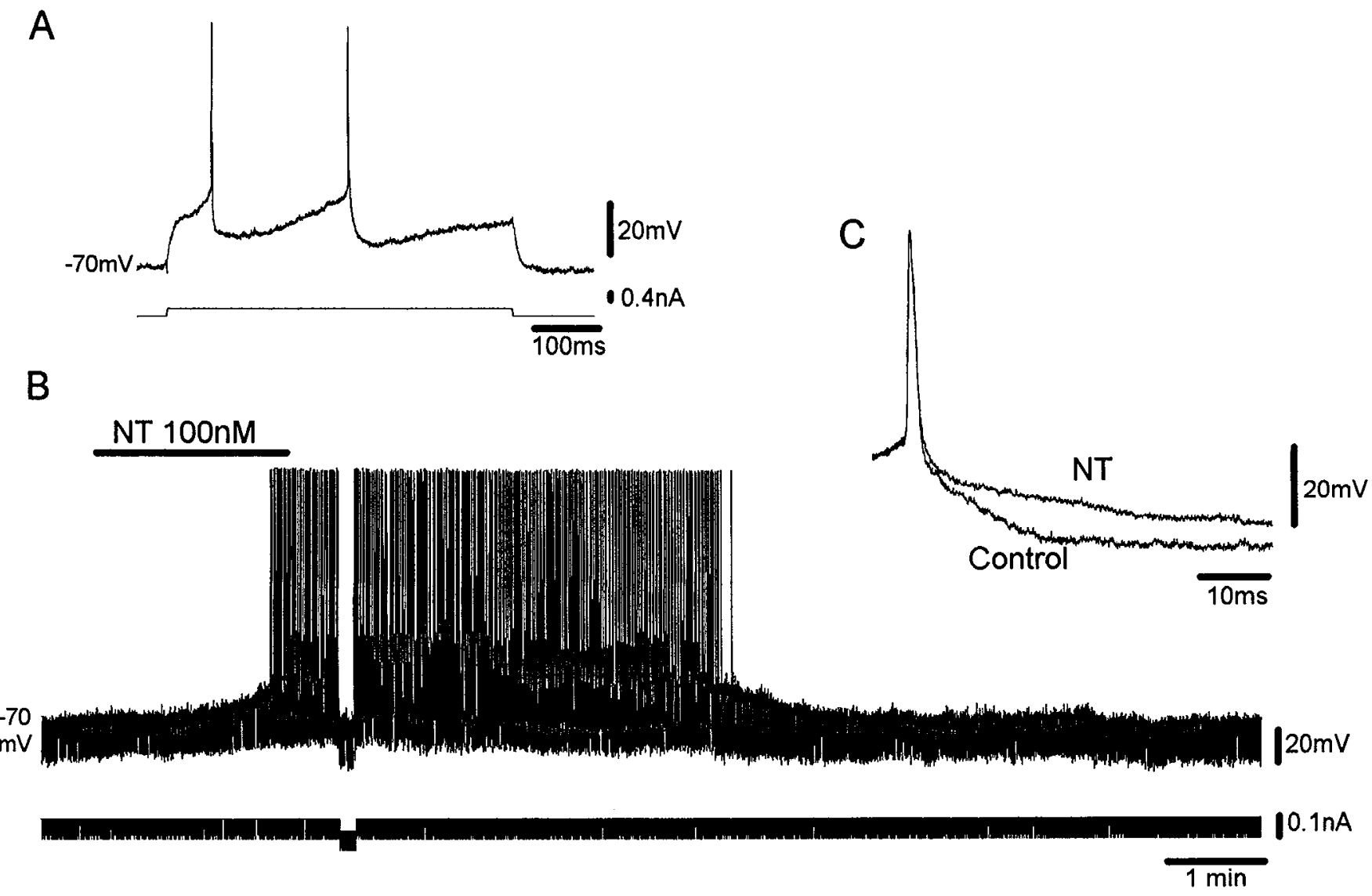

Figure 13. NT also depolarizes nonbursting, potentially cholinergic, BF neurons that displayed broad spikes followed by large-amplitude longlasting afterhyperpolarizations. $A$, Depolarizing constant-current pulse injection elicits broad spikes followed by a large-amplitude sAHP in a BF neuron. $B$, Bath application of NT to this cell elicits a membrane potential depolarization associated with a decrease in input conductance and sustains repetitive single spiking. $C$, Superimposition of an action taken potential before (control) and during NT action. Note that similarly to the bursting cholinergic cells, NT substantially reduced the SAHP.

activation. Indeed, several studies have identified a group of BF projection neurons that fire at low rates during slow-wave sleep (SWS) and increase their rates during waking and paradoxical sleep (Détári and Vanderwolf, 1987; Détári et al., 1984, 1987; Buzsàki et al., 1988). Interestingly, many of these cells switched to a bursting mode during SWS (Délári et al., 1987). This observation may help to interpret other contrasting investigations implicating the BF in the control of sleep (Sterman and Clemente, 1962; Szymusiak and McGinty, 1986, 1989). One may envisage the rhythmic bursting pattern of BF cholinergic cells to operate during SWS while single spiking could be implemented during cortical arousal.

Clearly, for a thorough understanding of the role of NT in BF function, further information on the neurophysiological and chemoanatomical organization of the $\mathrm{BF}$ is needed. For instance, the origin of the BF NT innervation is still unknown. Furthermore, NT actions should be considered in the context of its interactions with other neurotransmitters acting on $\mathrm{BF}$ cholinergic cells. The BF receives afferents from multiple neurotransmitter systems involved in the control of behavioral state (Jones and Yang, 1985; Semba et al., 1988; Jones and Cuello, 1989) but little is known of the actions of those neurotransmitters impinging upon BF cholinergic cells, though some advances have recently been made (Khateb et al., 1991; Allen and Brown, 1993; Fort et al., 1993; Khateb et al., 1993).

Probably because of the paucity of information on the BF, the actions of NT on the cholinergic cells appear puzzling. By inducing depolarization and $G_{i}$ decrease, and by blocking both the TOR and the sAHP, NT can efficiently increase the responsiveness and activity of BF cholinergic cells. This is compatible with a role of NT in promoting cortical activation (Castel et al., 1989). However, the depolarizing effect of NT is accompanied by an enhancement of the BF cholinergic neurons oscillatory bursting. It might be that an enhanced complex-bursting pattern is indeed present during waking to promote $\mathrm{ACh}$ release. Such firing behavior may engage limbic cortices into theta oscillations. Indeed, limbic theta rhythmicity accompanies neocortical (apparent) desynchronization (Green and Arduini, 1954; Vanderwolf, 1969) and both processes are controlled by BF cholinergic influences (Stewart et al., 1984; Bland, 1986; Casamenti et al., 1986; Buzsàki et al., 1988; Stewart and Fox, 1990; Metherate et al., 1992).

On the other hand, it may be that the awakening effect reported after intracerebroventricular injections of NT (Castel et al., 1989) results from NT actions outside the BF. If so, an important role of the NT-induced rhythmic bursts may be that of modulating slow forebrain rhythms. The BF projects heavily upon the cortical mantle and receives a direct cortical feedback (Lemann and Saper, 1985; Carnes et al., 1990). In addition, both cholinergic and noncholinergic BF neurons project upon the thalamic nucleus reticularis (Steriade et al., 1987), which is a key element in the generation of different forms of oscillatory 
rhythms in the thalamocortical network (Steriade et al., 1985, 1986, 1993; Steriade and Llinás, 1988; von Krosigk et al., 1993). Under NT modulatory actions, the BF may perhaps be engaged as one more synaptically coupled oscillator to the thalamic and cortical ncuronal populations involved in the generation of basic slow wave rhythms of the forebrain.

\section{References}

Allen TGJ, Brown DA (1993) $\mathbf{M}_{2}$ muscarinic receptor-mediated inhibition of the $\mathrm{Ca}^{2+}$ current in rat magnocellular cholinergic basal forebrain neurones. J Physiol (Lond) 466:173-189.

Allen TGJ, Sim JA, Brown DA (1993) The whole-cell calcium current in acutely dissociated magnocellular cholinergic basal forebrain neurones of the rat. J Physiol (Lond) 460:91-116.

Alonso A, Faure MP, Beaudet A (1992) Neurotensin induces sustained rhythmic bursting activity and is internalized in basal forebrain cholinergic neurons. Soc Neurosci Abstr 18:761.

Armstrong DM, Saper CB, Levey AI, Wainer BH, Terry RD (1983) Distribution of cholinergic neurons in rat brain: demonstrated by the immunocytochemical localization of cholinc acetyltransfcrasc. J Comp Neurol 216:53-68.

Audinat E, Hermel J-M, Crépel F (1989) Neurotensin-induced excitation of neurons of the rat's frontal cortex studied intracellularly in in vitro. Exp Brain Res 78:358-368.

Behbehani MM, Shipley MT, McLean JH (1987) Effect of neurotensin on neurons in the periaqueductal gray. J Neurosci 7:2035-2040.

Belardetti F, Borgia R, Mancia M (1977) Proencephalic mechanisms of $\mathrm{ECoG}$ desynchronization in cerveau isole cats. Electroencephalogr Clin Neurophysiol 42:213-235.

Bland BH (1986) The physiology and pharmacology of hippocampal formation theta rhythms. Prog Neurobiol 26:1-54.

Buzsàki G, Bickford RG, Ponomareff G, Thal LJ, Mandel R, Gage FH (1988) Nucleus basalis and thalamic control of neocortical activity in the freely moving rat. J Ncurosci 8:4007-4026.

Candy JM, Perry RH, Thompson JE, Johnson M, Oakley AE (1985) Neuropeptide localization in the substantia innominata and adjacent regions of the human brain. J Anat 140:309-327.

Carnes KM, Fuller AT, Price JL (1990) Sources of presumptive glutamatergic/aspartatergic afferents to the magnocellular basal forebrain in the rat. J Comp Neurol 302:824-852.

Casamenti F, Deffenu G, Abbamondi A, Pepeu G (1986) Changes in cortical acetylcholine output induced by modulation of the nucleus basalis. Brain Res Bull 16:689-695.

Castel M-N, Stutzmann J-M, Lucas M, Lafforgue J, Blanchard J-C (1989) Effects of ICV administration of neurotensin and analogs on EEG in rats. Peptides 10:95-101.

Celesia GG, Jasper HH (1966) Acetylcholine released from cerebral cortex in relation to state of activation. Neurology 16:1053-1070.

Chabry J, Gaudriault G, Vincent JP, Mazella J (1993) Implication of various forms of neurotensin receptors in the mechanism of internalization of neurotensin in cerebral neurons. J Biol Chem 268:1713817144.

Checler F, Vincent J-P, Kitabgi P (1986) Neuromedin N: high affinity interaction with brain neurotensin receptors and rapid inactivation by brain synaptic peptidases. Eur J Pharmacol 126:239-244.

Coulter DA, Huguenard JR, Prince DA (1989) Calcium currents in rat thalamocortical relay neurones: kinetic properties of the transient, low-threshold current. J Physiol (Lond) 414:587-604.

Crunelli V, Lightowler S, Pollard CE (1989) A T-type Ca ${ }^{2+}$ current underlies low-threshold $\mathrm{Ca}^{2+}$ potentials in cells of the cat and rat lateral geniculate nucleus. J Physiol (Lond) 413:543-561.

Détári L, Vanderwolf CH (1987) Activity of identified cortically projecting and other basal forebrain neurones during large slow waves and cortical activation in anaesthetized rats. Brain Res 437:1-8.

Détári L, Juhász G, Kukorelli T (1984) Firing properties of cat basal forebrain neurones during sleep-wakefulness cycle. Electroencephalogr Clin Neurophysiol 58:362-368.

Détári L, Juhász G, Kukorelli I (1987) Neuronal firing in the pallidal region: firing patterns during sleep-wakefulness cycle in cats. Electroencephalogr Clin Neurophysiol 67:159-166.

Dobner PR, Barber DL, Villa-komaroff L, McKierman F (1987) Cloning and sequence analysis of cDNA for the canine neurotensin/neuromedin N precursor. Proc Natl Acad Sci USA 84:3516-3250.
Farkas R, Grigg JJ, Nakajima S, Nakajima Y (1992) Effects of neurotensin on magnocellular cholinergic neurons from the nucleus basalis. Soc Neurosci Abstr 17:1500.

Faure MP, Shaw I, Gaudreau P, Cashman NR, Beaudet A (1992) Binding and internalization of neurotensin in hybrid cells derived from septal cholinergic neurons. Ann NY Acad Sci 688:345-347.

Fisher RS, Buchwald NA, Hull CD, Levine MS (1988) GABAergic basal forebrain neurons project to the neocortex: the localization of glutamic acid decarboxylase and choline acctyltransferase in felinc corticopetal neurons. J Comp Neurol 272:489-502.

Fort P, Khateb A, Pegna M, Mühlethaler M, Jones BE (1993) Characterization of a noradrenergic excitatory effect on cholinergic neurones of the nucleus basalis in guinea-pig brain slices. Soc Neurosci Abstr 19:1375.

Green JD, Arduini A (1954) Hippocampal electrical activity in arousal. J Neurophysiol 17:533-557.

Griffith WH (1988) Membrane properties of cell types within guinea pig basal forebrain nuclei in vitro. J Neurophysiol 59:1590-1612.

Griffith WH, Mathews RT (1986) Electrophysiology of AChE-positive neurons in basal forebrain slices. Neurosci Lett 71:169-174.

Gritti I, Mainville L, Jones BE (1993) Codistribution of GABA- with acetylcholine-synthesizing neurons in the basal forebrain of the rat. J Comp Ncurol 329:438-457.

Haber SN, Watson SJ (1985) The comparative distribution of enkephalin, dynorphin and substance $P$ in the human globus pallidus and basal forebrain. Neuroscience 14:1011-1024.

Hille B (1992) Ionic channels of excitable membranes. Sunderland, MA: Sinauer.

Hopkins CR, Gibson A, Shipman M, Miller K (1990) Movement of internalized ligand-receptor complexes along a continuous endosomal reticulum. Nature 346:335-339.

Huguenard JR, Prince DA (1992) A novel T-type current underlies prolonged $\mathrm{Ca}^{2+}$-dependent burst firing in GABAergic neurons of rat thalamic reticular nucleus. J Neurosci 12:3804-3817.

Huguenard JR, Gutnick MJ, Prince DA (1993) Transient Ca ${ }^{2+}$ currents in neurons isolated from rat lateral habenula. J Neurophysiol 70:158-167.

Jahnsen H, Llinás R (1984a) Electrophysiological properties of guineapig thalamic neurones: an in vitro study. J Physiol (Lond) 349:205226

Jahnsen H, Llinás R (1984b) Ionic basis for the electroresponsiveness and oscillatory properties of guinea-pig thalamic neurones in vitro. $\mathrm{J}$ Physiol (Lond) 349:227-247.

Jasper HH, Tessier J (1971) Acetylcholine liberation from cerebral cortex during paradoxical (REM) sleep. Science 172:601-602.

Jones BE, Cuello AC (1989) Afferents to the basal forebrain cholinergic cell area from pontomesencephalic-catecholamine, serotonin, and acetylcholine-neurons. Neuroscience 31:37-61.

Jones BE, Yang T-Z (1985) The efferent projections from the reticular formation and locus coeruleus studied by anterograde and retrograde axonal transport in the rat. J Comp Neurol 242:56-92.

Kanai T, Szerb JC (1965) Mesencephalic reticular activating system and cortical acetylcholine output. Nature 205:80-82.

Khachaturian H, Lewis ME, Haber SN, Akil H, Watson SJ (1984) Proopiomelanocortin peptide immunocytochemistry in thesus monkey brain. Brain Res Bull 13:785-800.

Khateb A, Serafin M, Jones BE, Alonso A, Mühlethaler M (1991) Pharmacological study of basal forebrain neurons in guinea pig brain slices. Soc Neurosci Abstr 17:881.

Khateb A, Mühlethaler M, Alonso A, Serafin M, Mainville L, Jones BE (1992) Cholinergic nucleus basalis neurons display the capacity for rhythmic bursting activity mediated by low threshold calcium spikes. Neuroscience 51:489-494.

Khateb A, Fort P, Alonso A, Jones BE, Mühlethaler M (1993) Pharmacological and immunohistochemical evidence for serotonergic modulation of cholinergic nucleus basalis neurons. Eur J Neurosci 5:541-547.

Klink R, Faure MP, Kay AR, Alonso A (1993) Diversity of $\mathrm{Na}$ and Ca currents in cholinergic nucleus basalis neurons. Soc Neurosci Abstr 19.

Köhler C, Chan-Palay V, Wu J-Y (1984) Septal neurons containing glutamic acid decarboxylase immunoreactivity project to the hippocampal region. Anat Embryol (Berl) 169:41-44.

Kurosawa M, Sato A, Sato Y (1989) Stimulation of the nucleus basalis of Meynert increases acetylcholine release in the cerebral cortex in rats. Neurosci Lett 98:45-50. 
Lemann W, Saper CB (1985) Evidence for a cortical projection to the magnocellular basal nucleus in the rat: an electron microscopic axonal transport study. Brain Res 334:339-343.

Lo Conte G, Casamenti F, Bigl V, Milaneschi E, Pepeu G (1982) Effect of magnocellular forebrain nuclei lesions on acetylcholine output from the cerebral cortex, electrocorticogram and behavior. Arch Ital Biol 120:176-188.

Mai JK, Triepel J, Metz J (1987) Neurotensin in the human brain. Neuroscience 22:499-524.

Markram H, Segal M (1990) Electrophysiological characteristics of cholinergic and non-cholinergic neurons in the rat medial septumdiagonal band complex. Brain Res 513:171-174.

Mazella J, Leonard K, Chabry J, Vincent J-P, Beaudet A (1991) Binding and internalization of iodinated neurotensin in neuronal cultures from embryonic mouse brain. Brain Res 564:249-255.

McCormick DA (1991) Functional properties of a slowly inactivating potassium current in guinea pig dorsal lateral geniculate relay neurons. J Neurophysiol 66:1176-1189.

McCormick DA, Huguenard JR (1992) A model of the electrophysiological properties of thalamocortical relay neurons. J Neurophysiol 68:1384-1400.

McCormick DA, Pape H-C (1990) Properties of a hyperpolarizationactivated cation current and its role in rhythmic oscillation in thalamic relay neurones. J Physiol (Lond) 431:291-318.

Melander T, Staines WA, Hokfelt T, Rokaeus A, Eckenstein F, Salvaterra PM, Wainer BH (1985) Galanin-like immunoreactivity in cholinergic neurons of the septum-basal forebrain complex projecting to the hippocampus of the rat. Brain Res 360:130-138.

Metherate R, Cox CL, Ashe JH (1992) Cellular bases of neocortical activation: modulation of neural oscillations by the nucleus basalis and endogenous acetylcholine. J Neurosci 12:4701-4711.

Morin AJ, Jones BE, Beaudet A (1993) Codistribution of cholinergic neurons and neurotensinergic fibres in the rat basal forebrain. Soc Neurosci Abstr 19:492.

Mühlethaler M, Khateb A, Fort P, Jones BE, Alonso A (1992) Forty $\mathrm{Hz}$ membrane potential oscillations and theta-like activity in basal forebrain neurones. Soc Neurosci Abstr 18:197.

Nicoll RA (1978) The action of thyrotropin-releasing hormone, substance $\mathbf{P}$ and related peptides on frog spinal motoneurons. J Pharmacol Exp Ther 207:817-824.

Onteniente B, Tago H, Kimura H, Maeda T (1986) Distribution of gamma-aminobutyric acid-immunoreactive neurons in the septal region of the rat brain. J Comp Neurol 248:422-430.

Parton RG, Simons K, Dotti CG (1992) Axonal and dendritic endocytic pathways in cultured neurons. J Cell Biol 119:123-137.

Pinnock RD (1985) Neurotensin depolarizes substantia nigra dopamine neurons. Brain Res 338:151-154.

Kaggenbass M, Goumaz M, Sermasi E, Tribollet E, Dreifuss JJ (1991) Vasopressin generates a persistent voltage-dependent sodium current in a mammalian motoneuron. J Neurosci 11:1609-1616.

Robinson TE, Kramis RC, Vanderwolf CH (1977) Two types of cerebral activation during active sleep: relations to behavior. Brain Res 124:544-549.

Rye DB, Wainer BH, Mesulam M-M, Mufson EJ, Saper CB (1984) Cortical projections arising from the basal forebrain: a study of cholinergic and noncholinergic components employing combined retrograde tracing and immunohistochemical localization of choline acetyltransferase. Neuroscience 13:627-643.

Sawada S, Takada S, Yamamoto C (1980) Electrical activity recorded from thin sections of the bed nucleus of the stria terminalis, and the effects of neurotensin. Brain Res 188:578-581.

Semba K, Reiner PB, McGeer EG, Fibiger HC (1988) Brainstem afferents to the magnocellular basal forebrain studied by axonal transport, immunohistochemistry, and electrophysiology in the rat. J Comp Neurol 267:433-453.

Seutin V, Massotte L, Dresse A (1989) Electrophysiological effects of neurotensin on dopaminergic neurones of the ventral tegmental area of the rat in vitro. Neuropharmacology 28:949-954.
Shi W-X, Bunney BS (1992) Actions of neurotensin: a review of the electrophysiological studies. Ann NY Acad Sci 668:129-145.

Shute CCD, Lewis PR (1967) The ascending cholinergic reticular systems: neocortical, olfactory and subcortical projections. Brain 90:497520.

Smith Y, Parent A, Kerkerian L, Pelletier G (1985) Distribution of neuropeptide $Y$ immunoreactivity in the basal forebrain and upper brainstem of the squirrel monkey (Saimiri sciureus). J Comp Neurol 236:71-89.

Stanzione P, Zieglgansberger W (1983) Action of neurotensin on spinal cord neurons in the rat. Brain Res 268:111-118.

Steriade M, Llinás RR (1988) The functional states of the thalamus and the associated neuronal interplay. Physiol Rev 68:649-742.

Stcriadc M, McCarley RW (1990) Brainstem control of wakefulness and sleep. New York: Plenum.

Steriade M, Deschenes M, Domich L, Mulle C (1985) Abolition of spindle oscillations in thalamic neurons disconnected from nucleus reticularis thalami. J Neurophysiol 54:1473-1497.

Steriade M, Domich L, Oakson G (1986) Reticularis thalami neurons revisited: activity changes during shifts in states of vigilance. $J$ Neurosci $6: 68-81$.

Steriade M, Parent A, Paré D, Smith Y (1987) Cholinergic and noncholinergic neurons of cat basal forebrain project to reticular and mediodorsal thalamic nuclei. Brain Res 408:372-376.

Steriade M, Contreras D, Curró Dossi R, Nuñez. A (1993) The slow $(<1 \mathrm{~Hz})$ oscillation in reticular thalamic and thalamocortical neurons: scenario of sleep rhythm generation in interacting thalamic and neocortical networks. J Neurosci 13:3284-3299.

Sterman MB, Clemente CD (1962) Forebrain inhibitory mechanisms: sleep patterns induced by basal forebrain stimulation in the behaving cat. Exp Neurol 6:103-117.

Stewart DJ, MacFabe DF, Vanderwolf CH (1984) Cholinergic activation of the electrocorticogram: role of the substantia innominata and effects of atropine and quinuclidinyl benzylate. Brain Res 322 : 219-232.

Stewart M, Fox SE (1990) Do septal neurons pace the hippocampal theta rhythm? Trends Neurosci 13:163-168.

Szigethy E, Wenk GL, Beaudet A (1989) Anatomical substrate for neurotensin-acetylcholine interactions in the rat basal forebrain. Peptides 9:1227-1234

Szigethy E, Leonard K, Beaudet A (1990) Ultrastructural localization of [125I]neurotensin binding sites to cholinergic neurons of the rat nucleus basalis magnocellularis. Neuroscience 36:377-391

Szymusiak R, McGinty D (1986) Sleep suppression following kainic acid-induced lesions of the basal forebrain. Exp Neurol 94:598-614.

Szymusiak R, McGinty D (1989) Sleep-waking discharge of basal forebrain projection neurons in cats. Brain Res Bull 22:423-430.

Vanderwolf $\mathrm{CH}$ (1969) Hippocampal electrical activity and voluntary movement in the rat. Electroencephalogr Clin Neurophysiol 26:407418.

Vanderwolf $\mathrm{CH}$ (1975) Neocortical and hippocampal activation in relation to behavior: effects of atropine, eserine, phenothiazines and amphetamine. J Comp Physiol Psychol 88:300-323.

Vanderwolf $\mathrm{CH}$ (1988) Cerebral activity and behavior: control by central cholinergic and serotoninergic systems. Int Rev Neurobiol 30: 225-340.

Vanisberg MA, Malotaux J-M, Octave J-N, Laudron PM (1991) Rapid agonist-induced decrease of neurotensin receptors from the cell surface in rat cultured neurons. Biol Pharmacol 42:2265-2274.

von Krosigk M, Bal T, McCormick DA (1993) Cellular mechanisms of a synchronized oscillation in the thalamus. Science 261:361-364.

Walker LC, Koliatsos VE, Kitt CA, Richardson RT, Rökaeus \& (1989) Peptidergic neurons in the basal forebrain magnocellular complex of the rhesus monkey. J Comp Neurol 280:272-282.

Zaborszky L, Carslen J, Brashear HR, Heimer L (1986) Cholinergic and GABAergic afferents to the olfactory bulb in the rat with special emphasis on the projection neurons in the nucleus of the horizontal limb of the diagonal band. J Comp Neurol 243:488-509. 